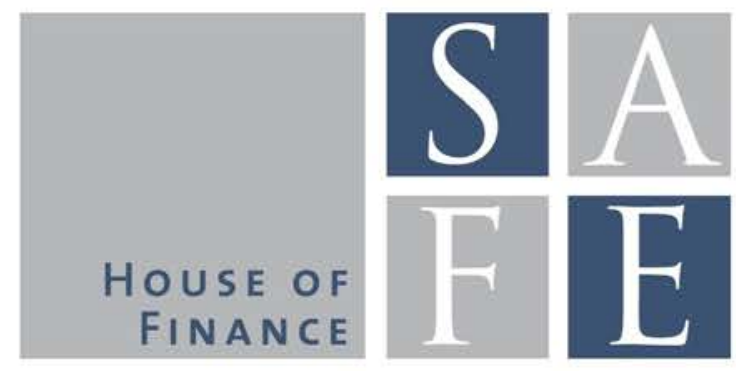

WORKING PAPER SERIES

Jannic Alexander Cutura

\title{
Debt Holder Monitoring and Implicit Guarantees: Did the BRRD Improve Market Discipline?
}

SAFE Working Paper No. 232

SAFE I Sustainable Architecture for Finance in Europe A cooperation of the Center for Financial Studies and Goethe University Frankfurt 


\section{Non-Technical Summary}

The financial crisis of 2007-2009 resulted in a series of unprecedented tax payer funded bailouts for financial institutions, with some entities remaining in public conservatorship to date. Letting banks fail and have them enter bankruptcy procedures was perceived as too socially costly given the negative externalities on the real economy (in the form of credit supply contraction and the destruction of lending relationship which cannot be easily substituted). Those bailouts, however, are politically costly as they support the narrative that profits are privatized while losses are socialized. Moreover, they diminish incentives for bank debt investors (bond holders) to monitor risk taking, increasing the likelihood of future banking failures. To restore market discipline, the European Union passed the Banking Recovery and Resolution Directive (BRRD), a set of binding rules to deal with banks in distress. Most importantly, it features a bail-in tool. In a bail-in, unsecured bonds can be written off or converted into equity to recapitalize banks as a going concern without having them enter bankruptcy procedures. This new tool should allow supervisors to escape the prisoner's dilemma of either using tax payer money to save banks or risk negative fallout on the economy by letting banks fail. It is unclear, however, whether investors perceive the bail-in threat as credible commitment.

This study exploits exogenous variation in the treatment of bank bonds depending on their respective maturity. As the BRRD was passed in April 2014 and the bail-in tool is not to be used until January 2016, applicable bank bonds maturing in 2015 and 2016+ are treated differently. If the BRRD is perceived as credible, the yield spread (a common measure of a bonds credit risk) should respond to the BRRD only for bonds maturing in 2016 and onwards. Indeed, this setup allows to establish causality given the plausibly exogenous variation. The results of a difference-in-difference regression estimate a bail-in premium of about 10-15 basis points on a sample of 1,491 bonds by 53 European banks. The bail-in premium is mainly driven by (low) bank capital. Lower equity increases the perceived likelihood of default which is priced in for bonds maturing in 2016+ (which are therefore subject to BRRD bail-in) more than for bonds maturing in 2015 (which are protected from BRRD bail-in). Overall, the results strongly favour the hypothesis that the BRRD improved market discipline in the European banking sector. 


\title{
Debt holder monitoring and implicit guarantees: Did the BRRD improve market discipline?
}

\author{
Jannic Alexander Cutura*
}

This version: September 25, 2018

\begin{abstract}
This paper argues that the introduction of the Banking Recovery and Resolution Directive (BRRD) improved market discipline in the European bank market for unsecured debt. The different impact of the BRRD on bank bonds provides a quasi-natural experiment that allows to study the effect of the BRRD within banks using a difference-in-difference approach. Identification is based on the fact that (otherwise identical) bonds of a given bank maturing before 2016 are explicitly protected from BRRD bail-in. The empirical results are consistent with the hypothesis that debt holders actively monitor banks and that the BRRD diminished bail-out expectations. Bank bonds subject to BRRD bail-in carry a 10 basis points bail-in premium in terms of the yield spread. While there is some evidence that the bail-in premium is more pronounced for non-GSIB banks and banks domiciled in peripheral European countries, weak capitalization is the main driver.
\end{abstract}

JEL Codes: G18, G21, H81

\footnotetext{
${ }^{*}$ Goethe University Frankfurt, eMail address: cutura@finance.uni-frankfurt.de I would like to thank Inaki Aldosoro, Martin Götz, Rainer Haselmann, Henning Hesse, David Ibanez, Michael Koetter, Jan Krahnen, Ulf Lewrick, Maximilian Mayer, Thomas Mosk, Steven Ongena, Gianpaolo Parise, Loriana Pelizzon, Oliver Schlüter, Andreas Schrimpf and Yannick Thimmer as well as participants from the IFWSAS 2018, the $15^{\text {th }}$ Corporate Finance Day Antwerp, the SMYE 2018 conference, Goethe University's Brown Bag Seminar and the doctoral finance seminar in Rietzlern for helpful comments and suggestions. I gratefully acknowledge research support from the research center SAFE, funded by the State of Hessen initiative for research LOEWE. All remaining errors are my own.
} 


\section{Introduction}

The financial crisis of 2007-2009 resulted in a series of unparalleled public bailouts for the banking sector. Letting banks fail and enter bankruptcy procedures was deemed to be too socially expensive. The costs of a bailout seemed to be justified given the negative externalities of bank failures, not only on financial stability but also the real economy. While those bailouts presumably restored market confidence in the short-run, they may have further weakened market discipline. A central goal for banking regulation since the crisis was therefore to provide mechanisms to ensure that equity and debt-holders participate in losses of potential future bank failures without having the respective bank to enter bankruptcy procedures. In Europe, the Banking Recovery and Resolution Directive (BRRD) provides tools to recapitalize banks by converting outstanding debt (unsecured bonds) into equity - a so called bail-in. This bail-in threat should exante increase market discipline. Yet it remains unclear whether it achieved its purpose. How credible are banking regulation reforms attempting to strengthen market discipline by eliminating implicit government guarantees?

This paper answers this question by studying the impact of the BRRD on bonds subject to bail-in. It contributes to the literature as it is (to my best knowledge) the first paper that studies how a change in the regulatory architecture (that is a change in the supervisors ability to enforce laws, rather than either a change in laws itself or a change in banks risk profiles) is perceived by debt-holders. It capitalizes on a novel identification strategy which allows to study the effect of the BRRD on market discipline using within bank variation. Key to being able to use variation within banks is the fact that for a given bank, bonds are differently affected by the change in the bail-in regulation depending on their respective maturity. The BRRD was passed in the European Parliament on 15/04/2014 and was to be implemented to national law by member states by $01 / 01 / 2015$, with 
the exception of the bail-in tool, which was to be implemented by $01 / 01 / 2016$ to give markets enough time to adjust. Therefore consider two bonds, \#1 and \#2, both issued by Bank A before June 2012. Bond \#1 matures, say 01.06.2016 and bond \#2 matures 01.06.2015. If investors did not believe the bail-in tool to be a credible threat, then the introduction of the BRRD should not affect the yield spreads of the two bonds differently. If the BRRD is however perceived as credible, it should only increase the yield spread of bond \#1, because it is ex-post subject to BRRD bail-in, while bond \#2 is explicitly protected. The advantage of this setting is that the variation is plausibly exogenous and that within bank variation allows to control for unobserved heterogeneity since bond level data allows for bond and bank $\times$ month fixed effects.

Employing this novel identification strategy, I am able to show that unsecured bank bonds which suffer from unexpected BRRD bail-in exposure face increased yield spreads of about 10-15 basis points compared to the control group - a pattern that cannot be observed for non-bank corporate bonds. This bail-in premium is mainly driven by weak capitalization. Also, the effect is less pronounced for Globally Systemic Important Banks (GSIB) and for banks of peripheral European countries (albeit not statistically significantly). The empirical evidence strongly favours the hypothesis that the BRRD indeed improved market discipline, by demanding a premium for unsecured liabilities that are subject to bail-in. A battery of robustness checks is provided, including parallel trends test and placebo tests.

These results contribute to the growing literature on debt-holder monitoring and market discipline and implicit guarantees. As pointed out in Bliss and Flannery (2002) market discipline is characterized by two distinct features, which are firstly the ability of debt holders to monitor risk-taking and secondly their ability to influence the managers behaviour based on their assessment. After the financial crisis a third feature attracted increased attention. Debt holders have to ex-ante believe that they will share the burden of losses in case of a bank fail- 
ure if they are supposed to have any incentive to monitor risk taking in the first place (Hett and Schmidt 2017). Hence there are two fundamental mechanisms at work here, which have been subject to intensive research in the past. The first is related to debt-holders ability to monitor and influence bank risk taking. Regarding debt-holders ability to understand the risks taken by banks, most studies try to relate market prices of bank securities (shares and bonds) to their underlying risk profile. The majority (and in particular more recent studies) conclude that investors are indeed able to price those risks (Martinez Peria and Schmukler (2001), Jagtiani et al. (2002), Goldberg and Hudgins (2002), Longstaff et al. (2005) and Bennett et al. (2015)). Less research has been done on debt holders' ability to influence bank risk-taking. There is evidence that both supports (Ashcraft (2008), Ignatowski and Korte (2014) and Danisewicz et al. (2016)) and rejects (Billett et al. (1998) and Bliss and Flannery (2002)) the hypothesis that debt-holders are able to govern bank risk taking. This debate is not only of academic interest but is also important for designing optimal regulatory frameworks (Calomiris 1999). Moreover it is fueling the debate on debt vs. equity as a disciplining mechanism in the banking sector (Admati et al. (2013), Hasan et al. (2015) and Jordà et al. (2017)). The second relevant branch of literature in this context concerns the optimal regulatory architecture and its impact on bank risk taking. While theoretic work both supports (Farhi and Tirole 2012) and rejects (Keeley (1990) and Hakenes and Schnabel (2010)) the hypothesis that implicit guarantees increase bank risk taking, the empirical evidence tends to support the view that expected government support induces moral hazard (Dam and Koetter (2012), Black and Hazelwood (2013) and Duchin and Sosyura (2014)). The time inconsistency problem at play is fairly simple: Even though ex-ante supervisors would have preferred to let banks fail, ex-post the risks and social costs associated with letting them fail seemed to justify the bailout. Letting banks enter bankcruptcy procedures, it is often argued, is not a subgame perfect strategy for the supervisor as there are 
states of the world in which ex-post she prefers a bail-out (Acharya and Yorulmazer (2007), DeYoung et al. (2013) and Papanikolaou (2018)). This "implicit guarantee" weakens debt holders incentives to monitor bank risk taking in the first place. Quantifying and eliminating this implicit guarantee has been a major goal in banking regulation since the crisis (for an overview see Schich and Lindh (2012). The BRRD can be thought of as an improvement in resolution technology. By converting debt into equity to recapitalize failing banks, supervisors are now able to recapitalize these institutions quickly and without risking negative externalities on the real economy. This is because banks will not have to enter bankruptcy procedures since converting debt to equity will restore the required capital ratios. The bail-in threat should therefore induce debt-holders to monitor bank risk taking. This should not only incentivize debt-holders to monitor, but also equity holders as their share will be written off or diluted, diminishing previously present implicit guarantees for equity holders (Kelly et al. 2016). How credible this threat is, is discussed not only among academics (Schäfer et al. (2016), Tröger (2018) and Raffaele Giuliana (2018)) but also policy advisors (Alexander (2013), Walther and Lucy (2015), Hadjiemmanuil (2015) and Philippon and Salord (2017)).

The remainder of this paper is structured as follows. Section 2 explains the identification strategy in greater detail. Section 3 discusses the data used. Section 4 presents the empirical results and provides various robustness checks. Finally, Section 5 section concludes.

\section{Identification Strategy}

This section presents the identification strategy employed in this paper. As outlined in the introduction, establishing causality is one of the major challenges in the literature on market discipline. Therefore, I first provide institutional back- 
ground knowledge on the BRRD and in particular the scope and implementation dates of the bail-in tool. Based on this information, I explain how difference-indifference methodology can be used in this context to study the impact of the BRRD on market discipline.

\subsection{Institutional Background}

Ever since the Great Recession various financial market regulation reforms have been brought in place around the world. The BRRD is the EU's effort to provide a common legislative framework to deal with banks which are failing or likely to fail. The European Commission (EC) published their first draft on 06/06/2012. Almost two years later, the final version of the directive passed the European Parliament on 15/04/2014. It defines under which conditions a banking institution is deemed to be failing or likely to fail and which consequences this can trigger. The bail-in tool is one of those. A bail-in (as opposed to a bail-out) occurs when bank creditors (e.g. investors in bank bonds) of a failing bank will either see their debt written off or converted into equity upon supervisory discretion to restore the viability of the institution ${ }^{1}$

The BRRD provides a detailed account on which liabilities are subject to the bail-in tool (Article 44), the creditor hierarchy (Article 34) and the implementation dates (Article 130). Acording to Article 130 of the BRRD, the directive is to be implemented into national laws by 1 January 2015. However provisions related to Section 5 of Chapter IV of Title IV (Article $43-58$ ) are to be implemented by 1 January 2016 (European Parliament 25/04/2014). These articles include the provisions on the bail-in tool and the MREL requirement. This

\footnotetext{
${ }^{1}$ Under the BRRD regime, a bail-in is a necessary condition for any government support. However, it can also be used to facilitate private sector M\&A solutions, such as with Banco Poplare D'Espagne (BPE) and Banco Santander, where junior debt of BPE was written off and Banco Santander purchased BPE for the symbolic price of one Euro.

${ }^{2}$ The first proposal on the BRRD published by the Comission actually required no use of the bail-in tool before 1 January 2018.
} 
grants an explicit guarantee, that BRRD bail-in will not be applied before January 2016. Of course, debt maturing before 2016 could still suffer losses in case of a bank entering bankruptcy procedures. The change in the regulatory environment therefore does not change the general nature of a given liability. It merely adds to the authorities toolbox to enforce existing regulation. That is, it is now possible to ensure debt-holders participation in losses resulting of bank failures without closing down the bank (i.e. without having the bank enter (socially costly) bankruptcy procedures). This can be understood as an improvement in resolution technology available to authorities. Before and after the BRRD was implemented in January 2016, unsecured bonds are potentially suffering losses from bank failure. In the pre-BRRD regime however, the social costs of forcing debt-holders to participate by letting the failed bank enter bankruptcy procedures, renders that alternative very expensive to the supervisor. Figure 2 graphically depicts how the bail-in tool is supposed to work. If a banking institution is likely too fail (e.g. expected losses are larger than equity), a BRRD bail-in would consist of firstly writing down all existing equity issues and secondly converting outstanding debt into new equity shares. Debt investors (bond holders) would thus become the new owners of the bank, potentially facing immediate losses if asset losses exceed the existing equity level.

\subsection{Difference-in-Difference estimation}

The staggered introduction of the BRRD serves as a quasi natural experiment in this analysis. Essentially, bonds maturing before January 2016 are protected by an explicit guarantee not to employ the bail-in tool beforehand. This is the ideal setup to employ a difference-in-difference (DiD) analysis. DiD methodology is a frequently used and well documented empirical method for program evaluation (Imbens and Wooldridge (2008) and Angrist and Pischke (2009)). It has 
been used extensivly to study the effects of policies on labor markets (Card and Krueger (2000) and Autor (2003)). More recently it has been applied in a similar context by Ignatowski and Korte (2014) to evaluate the introduction of the Orderly Liquidation Authority (OLA) on bank risk taking.

To employ a DiD methodology three key questions need to be answered: (1) Is the BRRD bail-in tool an improvement in resolution technology? (2) What is the control group, what is the treatment group? (3) When did the treatment take place? On a practical level, Conlon and Cotter (2014) analyse how the BRRD would have performed during the financial crisis of 2007 - 2009. They conclude that even in very adverse scenarios, depositors would never have to be bailedin, limiting the risks of potential bank-runs. The recent bail-in of Banco Popolare's (BPE) junior bond holders provides an excellent example of how the BRRD

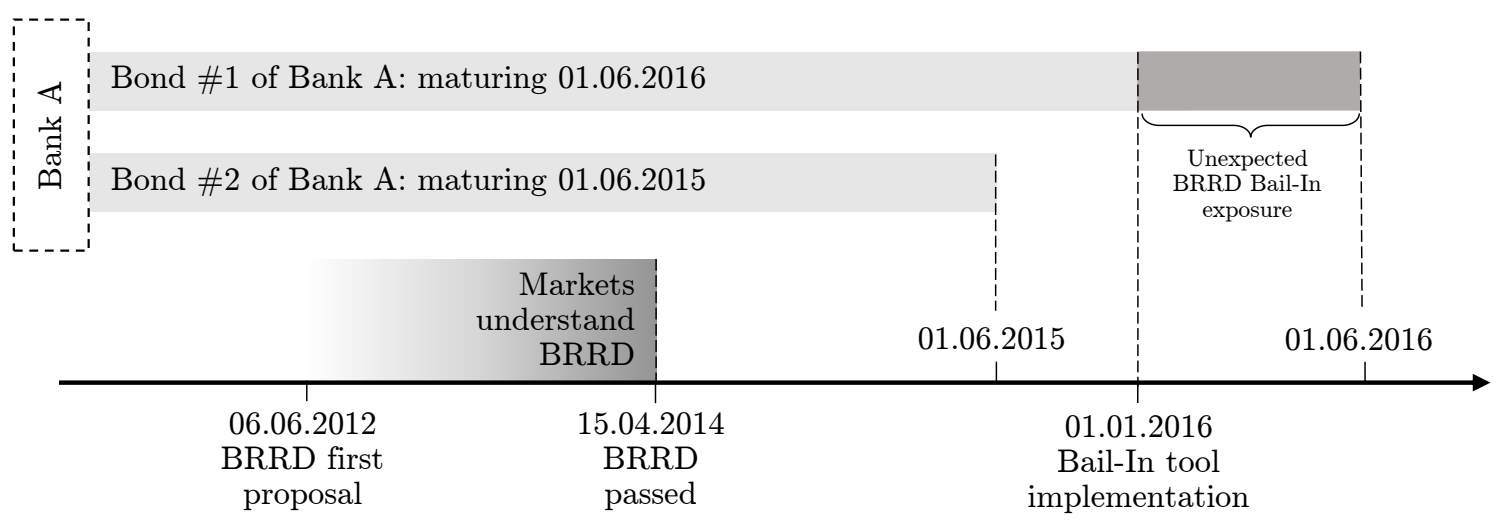

Figure 1: Identification Strategy

This graph plots the evolution of the legislative process. The European commission published the first draft of the BRRD on 06/06/2012. The European Parliament passed the final version on 15/04/2014. The law is to be implemented by $01 / 01 / 2015$, except for the bail-in tool, which is to be implemented by $01 / 01 / 2016$. Therefore, from a 2012 perspective, bonds \#1 and \#2 (both issued by Bank A) appear to have similar risk profiles. After the BRRD was passed however, investors understand that bond \#1 is subject to BRRD bail-in. If the BRRD is perceived as a credible threat, it should follow that bond \#1 will trade at a discount, that is face higher yield spreads compared to bond \#2. This set-up is therefore able to overcome the usual identification challenge by estimating the effect using within bank variation. 
is meant to work and demonstrates that it indeed provides the technology to force debt holders to participate in losses. On a theoretical level, a bail-in allows to have debt holders participate in losses without having the banks to enter bankruptcy procedures (which are socially costly given the associated negative externalities). This should make a bail-in the preferred strategy of the supervisor.

Identifying treatment and control group is fairly simple in this context. Bonds maturing before 2016 constitute the control group, while bonds maturing in 2016 and beyond belong to the treatment group

Identifying the treatment date is more difficult. In fact, one motivation of this research is that the imprecise event dates regarding the BRRD pose a severe challenge to event studies as performed by Schäfer et al. (2016). This is a well-known issue of event study methodology trying to evaluate the effect of regulation (Binder 1985). To avoid this problem, I define three periods. The pre-treatment period spans from $01 / 06 / 2011$ to $30 / 05 / 2012$, i.e. one year period before the European Commission published their first proposal. The posttreatment period ranges from $01 / 04 / 2014$ to $30 / 03 / 2015$, i.e. a one year period after the European Parliament passed the BRRD. Observations in between are dropped from the data set, since it is impossible to tell how much information has dispersed at what point in time.

\footnotetext{
${ }^{3}$ There is a valid concern regarding bonds maturing 2017 and later, as for those bonds the identification strategy might potentially yield spurious results. Parallel to the introduction of the bail-in tool, the BRRD also forces banks to fulfil a Minimum Requirement of Eligible Liabilities (MREL). After all, having a bail-in tool is only helpful if there is enough outstanding debt, that is subject to bail-in. Therefore the BRRD forces banks to have certain amounts of outstanding bailin-able securities. MREL is applicable from 01/01/2016 (just as the bail-in tool is). Therefore MREL can be considered as a positive supply shock of bailin-able bank debt. This could, all else equal, increase yield spreads of bonds maturing 2016 and later. It thus seems impossible to disentangle rising yield spreads in a bail-in premium and an equilibrium pricing induced $M R E L$ premium. There is however one important difference to note here. A bond only qualifies as MREL capital if its residual maturity is more than one year. Therefore all bonds maturing in 2016 are never part of any banks MREL capital and therefore not subject to a potential MREL premium. A robustness check verifies that the bail-in premium is also present on bonds maturing in 2016.
} 


\section{Data}

The main source of data is Bloomberg. For all Euro-zone banks used in Schäfer et al. (2016), I filter for Euro denominated bail-in-able bonds that were issued before 01.06.2012 and mature between 01.01.2015 and 31.12.2019. Table 12 describes the data selection process in detail. Next I download daily yield data 4 (variable code "YLD_CNV_LAST") from Bloomberg. The final sample contains 1,491 bonds of 53 banks. For a robustness check, I also download bonds yields for European non-financial corporates. Table 13 describes the data selection process for the non-bank corporate sample in detail.

The yield spread is computed by substracting the spot rate based on euro denominated European AAA government bond 55 with identical residual maturity, Yield $\operatorname{Spread}(i, t)=\operatorname{Yield}(i, t)-\operatorname{spotrate}(T T M(i, t))$ where $T T M(i, t)$ is the residual maturity of bond $i$ at time $t$. Finally monthly averages of the Yield Spreads are computed. Additionally I gather balance sheet data from SNL Financials. In particular the Core Equity Tier 1 ratio will be used to gauge bank risk 6 , Table 1 presents summary statistics.

\section{Results}

This section discusses my empirical results. The first subsection presents the main result of the paper, namely an increase in the yield spread for bonds suffer-

\footnotetext{
${ }^{4}$ I clean yield data the following way. All bonds that experience negative yields are dropped. The same percentage of bonds that are dropped from the "bottom" are subsequently also dropped from the top of the yield distribution. The reason for this filtering is a problem with stale price on Bloomberg. Price data is sometimes carried forward and not refreshed. Approaching maturity with fixed prices increases (or decreases if the price is above 100) the yield of the respective bond exponentially. My filtering allows me to drop bonds that experience this problem.

${ }^{5}$ To this end I download yield curve data from the ECBs' statistical dataware house. In particular the daily yield curve can be fitted very well using five parameters based on the Svenson model (Svenson 1995).

${ }^{6}$ To avoid endogeneity concerns, in that banks exposure to BRRD might have influenced their balance sheet structure, I use balance sheet data from 2010-2012.
} 
ing from BRRD bail-in exposure. I continue by exploring the cross sectional heterogeneity of my dataset and show that the bail-in premium is more pronounced for less capitalized banks. Finally, these results are complemented by a battery of robustness checks, including a parallel trends test and two placebo tests.

\subsection{Baseline specification \& heterogeneous effects}

First the hypothesized effect of the BRRD on bond yield spreads are tested using a multivariate difference-in-difference regression. The treatment dummy is equal to zero if the bonds matures before 2016 and one otherwise. The treatment period dummy is equal to zero for the year prior to the first BRRD proposal (i.e. from June 2011 to May 2012) and equal to one after the BRRD was passed (i.e. from April 2014 to May 2015). The intuition of this specification is that bonds maturing before 2016 are protected from BRRD bail-in and therefore associated with the control group, while bonds maturing after January 2016 are subject to bail-in. The idea of the treatment period dummy variable is to define a one year pre-treatment period and a one year post-treatment period and drop all observations that happened during the legislative procedure 7 . The interaction between the two is called $\operatorname{DiD}(i, t)$. The hypothesis is that there is no significant difference in the yield spread of the treatment and control group before the legislative process, but a significant (and positive) difference afterwards 8 I am running the

\footnotetext{
${ }^{7}$ This is done since it is difficult to tell at which point in time information about the BRRD was released to stakeholders. My approach is robust to including the period dropped for any meaningful choice of treatment date.

${ }^{8}$ The identifying assumption here (parallel trends of treatment and control group in absence of treatment) is intuitively plausible and in more detail discussed in a later subsection, which includes a parallel trends test.
} 
following baseline regression:

Yield $\operatorname{Spread}(i, t)=\beta_{0}+\beta_{1} \cdot \operatorname{DiD}(i, t)+\beta_{2} \cdot \operatorname{Treatment} \operatorname{Dummy}(i)$

$$
+ \text { Treatment Period Dummy }(t)+\beta_{4} \cdot X_{i t}+\gamma_{i}+\delta_{j} \times \mu_{t}+u_{i t}
$$

where Yield Spread $(i, t)$ is bond $i$ 's yield spread at month $t . X_{i t}$ is a vector of bond controls (in particular residual maturity) and $\gamma_{i}$ and $\delta_{j} \times \mu_{t}$ are bond and bank-month fixed effects respectively 9 , Standard errors are clustered on bond level (throughout the paper). The coefficient of interest is $\beta_{1}$. If the BRRD improved market discipline, one would expect $\beta_{1}$ to be positive. This would suggest that a bond which matures in 2016 or later (and therefore becomes subject to BRRD bail-in regulation) is viewed as more risky (as measured by the yield spread) after the BRRD is passed than a similar bond of the same institution which matures in 2015 (and is therefore exempt from BBRD bail-in). Note that given bank $\times$ month fixed effects explicitly controlling for macro factors (such as Libor or VIX) and bank characteristics (such as size or leverage) is not necessary, as these variables would be differenced out by design. Similarly, there is no need for a treatment period dummy as it would be differenced out by the month fixed effect, just like the treatment group dummy is differenced out by bond fixed effects (used in some specifications).

Table 2 presents the main results. Specification (1) is the simple differencein-difference regression (without any controls or fixed effects). Specficiation (2) and (3) add month and bond fixed effects, such that the treatment group dummy and the treatment period dummy are omitted. The difference-in-difference coefficient remains significant across all specifications and is with 15 basis points economically meaningful in magnitude. These three specifications however do

\footnotetext{
${ }^{9}$ Of course there is no need to include bank and month fixed effects separately once bank $x$ month fixed effects are included.
} 
not leverage the possibility to exploit variation within banks. The results could therefore be driven by cross sectional differences across banks, rather than differential treatment of bonds by the BRRD. Therefore, the remaining specifications of Table 2 include bank $\times$ month fixed effects, which control for a change in the risk profiles of the bonds respective banks. This is a major benefit of my identification strategy. Since bank $\times$ month fixed effects allow to difference out any (usually unobservable) change in bank riskiness, the change in the yield spreads must be caused by events which affects bonds of a given institution differently depending on their maturity. The positive and statistically highly significant difference-in-difference estimates in specification (4) - (7) do therefore not reflect an increase of the yield spread due to possibly increased riskiness of the respective bank. Instead they capture the differential impact of the BRRD on bonds maturing in 2015 (which are therefore protected from BRRD bail-in) and bonds maturing in 2016 and later (which are subject to BRRD bail-in) after the BRRD is passed compared to the pre-BRRD period. These results indicate that investors indeed perceive BRRD bail-in-able bonds to be more risky and demand a bail-in premium of about 10-15 basis points in terms of the yield spread. The most conservative specification (6) estimates a bail-in premium of 12.9 basis points, which remains virtually unchanged if one drops all observations with a remaining life of less than six months in specification (7) (to mitigate concerns regarding bond retirement effects). Given the 1.76 percentage point average of yield spreads in the sample, this is an economically sizeable effect of about $7 \%(=0.129 / 1.76)$. Investors seem to perceive bonds maturing in 2016 and later to be more risky than bonds maturing in 2015 after the BRRD was passed, compared to the period before the specifics of the BRRD were known.

As a next step I explore the cross sectional differences in my dataset. Intuitively the bail-in premium should be more pronounced for bonds of banks which investors perceive to be more likely to suffer from a bail-in. As explained earlier, 
those are the banks that are both more likely to fail and less likely to be saved. To proxy for bail-in risk I consider three categories: (i) capitalization level, (ii) GSIB status and (iii) domicile. Since equity represents a residual claim on the assets, capital can be thought of as a distance-to-default measure. As long as equity is not wiped out, debt holders will not suffer losses. Therefore a larger capital base is beneficial to debt investors, since it — ceteris paribus- decreases the likelihood of debt default. In order to capture the likelihood of being saved I consider two dimensions that are typically referred to in the debate, namely banks being too-big-too-fail (GSIB banks) and banks being located in peripheral European countries 10 .

Table 3 presents results for sample splits of my baseline specification described in equation (1). It indicates that the bail-in premium is more pronounced for (i) weakly capitalized ${ }^{11}$ banks (13.5 vs. 11.6 basis points), (ii) banks domiciles in peripheral countries (15.6 vs. 10.7 basis points) and (iii) non-GSIB banks (14.2 vs. 1.4 basis points). These findings are quite intuitive. The weaker the capitalization level of the banks, there higher the risk of bank failure is (ceteris paribus). If the BRRD is perceived as a credible threat, then bonds maturing in 2016+ should carry higher yield spreads for weaker capitalized banks. Similarly, if one is willing to accept the "too-big-too-fail" narrative, then one would expect a more pronounced bail-in premium for non-GSIB banks, reflecting their lower importance (and therefore the regulators higher willingness to let them fail). For banks domiciled in peripheral European countries, the effect is less clear ex-ante. On the one hand they are typically perceived as more risky (in particular regarding their exposure to non-performing loans (Dimitrios et al. 2016) and the diabolic loop (Brunnermeier et al.2016)). On the other hand, they are domiciled in countries which displayed some resistance to tighten and enforce resolution

\footnotetext{
${ }^{10}$ Typically Greece, Ireland, Italy, Spain and Portugal are considered.

${ }^{11}$ Weakly capitalized in this context means that the bank had below average CET1 capital ratio in 2010-2012 compared all other banks in the sample.
} 
regimes.

While sample splits can provide some intuition of cross sectional variation of treatment effects, Equation 2 interacts the difference-in-difference dummy with risk the measures to quantify the heterogeneity of the effect found in Table 3.

$$
\begin{aligned}
\operatorname{Yield} \operatorname{Spread}(i, t)=\beta_{0}+\beta_{1} \cdot \operatorname{DiD}(i, t)+\beta_{2} \operatorname{DiD}(i, t) & \times \operatorname{BailInRisk}(j) \\
& +\beta_{4} \cdot X_{i t}+\gamma_{i}+\delta_{j} \times \mu_{t}+u_{i t}
\end{aligned}
$$

where BailInRisk(j) is either the negative average standardized CET1 ratio in 2010-2012, or a dummy variable indicating peripheral domicile or non-GSIB status. The other variables remain unchanged.

Table 4 presents the results. In column (1) of Table 4 the baseline specification (without bail-in risk interaction) is displayed again for reference. Column (2) reveals the second major finding of this study: The bail-in premium is primarily driven by the capitalization level of banks. The difference-in-difference term here is interacted with the negative average standardized CET1 capital ratio (such that an increase can be interpreted as higher bail-in risk). Both the differencein-difference term as well as the triple interaction terms are statistically highly significant and economically meaningful. A one standard deviation decrease in equity is associated with a 16 basis points increase in the bail-in premium. Note that this is not driven by a general increase in bank risk (which is absorbed the bank $\times$ month fixed effects), but that it affects only those bonds which are not protected from BRRD bail-in. This is a new and conceptually different finding from the usual demonstration that yield spreads respond to changes in capital ratio (as demonstrated in M. J. Flannery and Sorescu (1996) and Sironi (2003)). Banks' riskiness (proxied by CET1 capital ratio in this case) affects bonds maturing in 2016 differently than bonds maturing a year earlier, since the latter are 
explicitly protected from BRRD bail-in. While it is well established that an increase in bank risk taking increases yield spreads of the banks securities, I show that an improvement in the supervisors ability to enforce participation in losses in case of bank failure, affects the yield spreads of applicable securities stronger for weakly capitalized banks.

Specification (3) and (4) interact the difference-in-difference term with a nonGSIB or a GIIPS dummy. As indicated in the sample splits, the bail-in premiums is more pronounced for non-GSIB banks and banks domiciled in peripheral countries. The difference is not statistically significant. This suggests that the driving force of the bail-in premium is related to the risk of bank failure rather than GSIB status or location. Note that this is in and of itself an interesting result: If the likelihood to fail is mainly responsible for the bail-in premium, than the BRRD is perceived as a credible threat across Europe and across institutions. This not a contradiction to the wide held belief that a failure of a major GSIB bank would lead to government intervention - it merely points out, that investors believe that they will be forced participate in the costs of restructuring (via a bail-in) to some degree. Overall, the presented evidence suggests that the BRRD improved market discipline in the European banking sector by removing implicit guarantees. Bank bonds investors perceive the bail-in tool as a credible threat, which is reflected in applicable securities yield spreads.

\subsection{Robustness Checks}

This subsection presents various robustness checks. It starts with a discussion of the identifying assumption of the difference-in-difference regression, namely parallel trends of control and treatment group in absence of treatment. Next I demonstrate that the same pattern cannot be observed on non-bank corporate bonds. I then turn to explore and MREL related explanation of the empirical re- 
sults. Finally I discuss potentially distorting effects related to Quantitative Easing and present a placebo test.

\section{Parallel Trends test}

The identifying assumption of any difference-in-difference analysis is the parallel trends assumption. In absence of treatment, both control and treatment group ought to have evolved similarly. In the context of this study, this assumption is quite intuitive. The yield spreads of two bonds of a given institution with identical characteristics (except one bond maturing in say 2015 and the other one in 2016) should be similar, as the term premium (for the longer life of the bond) are already accounted for in the spread. An advantage of panel data is that the parallel trends can be verified in the pre-treatment period statistically. To test the validity of the difference-in-difference setup, I evaluate the parallel trend assumption using a standard parallel trends test. This procedure is well established (see example Autor (2003)). The test os based on checking the statistical difference between treatment and control group in each period by introducing multiple difference-in-difference coefficients. More specifically one can estimate:

$$
\begin{aligned}
\text { Yield Spread }(i, t)=\sum_{k=\text { June } 2011}^{\text {May } 2012} m_{k} \cdot D_{i t}(t=k)+\sum_{k=\text { April } 2014}^{\text {March2015 }} p_{k} \cdot D_{i t}(t=k) \\
+\beta \cdot X_{i t}+\gamma_{i}+\delta_{j} \times \mu_{t}+\varepsilon_{i t}
\end{aligned}
$$

where $D_{i t}$ is a dummy variable that is equal to one if the bond is in the treatment group and the time is $t$. $\gamma_{i}$ and $\delta_{j} \times \mu_{t}$ are bond, and bank $\times$ month fixed effects respectively. $X_{i t}$ is a vector of bond controls. I exclude May 2012, thus estimating the dynamic effect of the BRRD on yield spreads relative to the last month of the pre-BRRD period, as is standard in the literature. For the difference- 
in-difference regression to be unbiased, the coefficients $m_{k}$ should be statistically insignificant different from zero, otherwise the treatment effect appears to take place before the treatment period started, pointing towards omitted variable bias caused by confounding, unobserved factors. The $p_{k}$ on the other hand should be significantly different from zero (and positive in this specific context). Table 5 presents the results. Indeed, there appears to be no difference between control and treatment group before the legislative process. After the BRRD was passed in parliament however, there is a positive and statistically significant difference, between bonds that are protected from BRRD bail-in and those that are not ${ }^{12}$. This suggests that the regression results of the previous section are indeed unbiased and provide consistent estimates. The results are graphically represented in Figure 3. The figure plots the coefficients and their $95 \%$ confidence intervals and at the same time foreshadows the results of the next subsection: The bail-in premium can be found only on bank bonds, not on non-bank corporate bonds.

\section{Non-bank corporate bonds}

As a first robustness check, I rerun the same regressions on non-bank corporate bonds which are constructed identically as the bank bonds sample. If the increase in yield spreads of securities which became exposed to BRRD bail-in is indeed driven by the BRRD, then the effect should only be present on bonds issued by banks, not bonds issued by corporates.

Table 7 presents the parallel trend test of the previous subsection for nonbank corporate bonds. Again, the coefficients in the pre-treatment period are insignificant, indicating valid research design. The coefficients in the treatmentperiod however are insignificant for corporate bonds. That is, the bail-in premium of the previous section cannot be found on non-bank corporate bonds. This makse sense, since the BRRD defines a new resolution regime only for banks

\footnotetext{
${ }^{12}$ Two pre-period interactions terms $m_{k}$ are significant but negative
} 
and not for corporations and should therefore have no impact on the latter. As the parallel trends test requires a lot of statistical power, the baseline regression is also computed again on the non-bank corporate bond sample. Table 6 presents the results. Column (1) and (2) include the entire sample of non-bank corporate bonds, with different fixed effects. Column (3) and (4) focus on bonds maturing in 2015 and 2016, as a robustness check which will be explained in the next subsection. The difference-in-difference coefficient varies between being positive and negative and remains statistically insignificant at any meaningful level across specifications. The fact that there is no effect on non-bank corporate bonds further supports the main result of this study: The BRRD improve market discipline in the European banking sector. The difference between bank and corporate bonds are visualized in Figure 3.

\section{MREL Equilibrium Pricing Effect}

Another concern regarding the interpretation of the empirical observations presented so far is related to the Minimum Requirements for Eligible Liabilities (MREL) which were introduced in the BRRD ${ }^{13}$. Since a bail-in requires a bank to have outstanding debt which qualifies for bail-in, the BRRD introduced a minimum requirement of such liabilities (the so called MREL). Starting 2016, authorities had the power to demand certain (at the time still to be determined) amounts of unsecured debt, such that in a banking failure there would be enough qualified debt outstanding to revive the bank by writing the debt off or converting it into equity. All else equal, mandating banks to issue more bail-in able debt (i.e. issue more bonds which share the same characteristics as the treatment group bonds in this study) should lead to an increase in the yields (and therefore the yield spreads) of all MREL qualifying bonds. Therefore, the empirical pattern

\footnotetext{
${ }^{13}$ I would like to thank Ulf Lewrick for pointing this out. See Crespi and Mascia (2018) for an analysis of MREL for the Italian banking sector
} 
observed so far, could well be explained by an "equilibrium MREL pricing effect". The exogenous shock (an increase in supply of such bonds forced by the regulator) would increase the yield spreads of outstanding securities sharing similar characteristics. Therefore it seems that the results presented sofar could be an MREL premium (due to increased supply of applicable securities) rather than a bail-in premium (reflecting increased bail-in risk). Fortunately, bonds only qualify as MREL if they have a residual maturity of a year (or longer). Given that MREL was introduced January 2016, any bond maturing in 2016 is potentially subject to a BRRD bail-in, but does not qualify as MREL (and therefore its yield spread should not experience an MREL premium). To test whether MREL could distort my results, I rerun the baseline regression, but limit the treatment group to bonds maturing in 2016 (while the control group remains unchanged and consists of bonds maturing in 2015). Table 8 presents the results. Specification (1) displays the main sample (including all bonds) for reference. The bail-in premium is still found on bonds maturing in 2016 (albeit the economic magnitude is somewhat smaller). The difference-in-difference coefficients remains significant in specification (2) - (4) and loses significance in specification (5), where the higher order residual maturity control term absorbs too much variation. Limiting the non-bank corporate sample on bonds maturing in 2015 and 2016 only, again finds no signs of a spurious results (as presented in Table 6 specification (3) and (4)).

\section{Quantitative Easing and Maturity Effects}

Yet another concern regarding the interpretation of the empirical observations presented so far is related to Quantitative Easing (QE) and the term structure of the yield (spread) curve. The sample period in this study coincides with various QE measures undertaken by the European Central Bank. When the short term rate hit the zero lower bound, the ECB tried to lower long term rates using un- 
conventional monetary policy measures. This "lowering of long term rates" may affect the treatment group in the dataset, differently than the control group, since by research design, the treatment group matures later. As described in section 3. I do not just subtract the current short-term rate from each bonds' yield, but the yield of a triple AAA rated government security with identical residual maturity. Therefore, all concerns regarding changes in (the slope of) the yield curve should be relaxed by the use of yield spreads rather than yields. Additionally, one might be concerned regarding the residual maturity as a control variable. I therefore rerun the baseline regression using residual maturity and different functions of it to see whether the effect is driven by the choice of residual maturity control variable(s). Table 9 presents the results. In specification (1) and (3), no maturity control is included and the difference-in-difference coefficient is quite large (22 basis points without bank controls and 16 basis with bank $\times$ month fixed effects). Controlling for different functions of residual maturity (in particular the log of residual maturity and higher order squared residual maturity) in specifications (4) - (7) the coefficient shrinks somewhat in magnitude (with 10 basis points, as "lower bound" estimate), but remains statistically highly significant across all specifications, suggesting the results are not driven by some mechanic effect in the yield spread structure.

\section{Placebo test using 2015 maturing bonds only}

As an additional (and final) robustness check, I construct a placebo test. As the BRRD bail-in is applicable from January 2016, one can construct a placebo test on bonds maturing in 2015. In this specification, the control group consists of bonds maturing in the first half of 2015, while the treatment group consists of bonds maturing in the second half of 2015. Note that both treatment and control group are explicitly protected from BRRD bail-in. The treatment group therefore experiences no actual treatment and is more accurately described as a placebo treat- 
ment group. Running the same baseline regression specification on this sample, one would expect no results, if BRRD bail-in is truly responsible for the observed pattern of the previous sections. Table 10 presents the results. Indeed, the difference in difference coefficient is not statistically significantly different from zero. Specification (4) and (5) additionally limit the sample by dropping all observations where the residual maturity is less than three months (to avoid concerns regarding retirement effects). Table 11 shows a parallel trend test for the placebo regression, which is graphically depicted along side the main sample in Figure 4.

\section{Scope of this research and policy implications}

Albeit the collected evidence strongly favours the hypothesis that the BRRD improved market discipline some limitations shall be pointed out before I conclude. First of all, the study only demonstrates that market discipline improved between 2011/2012 and 2014/15 as a result of the BRRD. Recent bank resolutions in Spain (with the successful bail-in of Banco Popolare d'Espanga junior debt investors) and Italy (with the back-door bail-out of retail investors of Monte de Paschi di Sienna) may have affected market discipline and bail-out expectations. As the identification strategy in this analysis uses bonds maturing in 2015 as the control group, any event after 2015 cannot be studied in this framework. Some evidence regarding the effects of recent bank resolution is presented in Raffaele Giuliana (2018). Second of all, wording matters crucially in this context. This studies only demonstrates that the BRRD decreased bail-out expectations. No claim is made regarding the absolute level of bail-out expectations before the BRRD, nor just how credible the bail-in threat is, now that the BRRD is in place. This is of great importance for policy makers. While the presented empirical evidence shows that the BRRD was indeed improving market discipline, it does not necessarily suggest that no additional measures should be undertaken to further diminish any remaining bail-out expectations. Lastly, some avenues for future research 
shall be pointed out. Since a successful bail-in depends on the creditors ability to suffer losses (and the regulators willingness to enforce those losses), an in depth analysis of the bank debt investor structure seems to be a promising avenue for future research (Boermans and van Wijnbergen 2017). In particular the exposure of retail investors (households) and insurance companies could be potentially dangerous pitfalls in enforcing bail-ins. Continuous monitoring of the debt holdings and their potential for bail-in cascades as documented in Hüser et al. (2017) could further be fruitful endeavour for regulators. Ultimately, the more knowledge supervisors have on the bail-in-able debt investors, the more credible the bail-in threat can be.

\section{Conclusion}

This paper exploits an unexplored natural experiment to inform the debate about market discipline in the European banking sector. Using the introduction of the BRRD bail-in tool which affects bonds maturing before and after 2016 differently, allows to examine debt holders ability to monitor bank risk taking and their perception of expected public assistance in the event of bank failure. This issue is of great importance to policy makers and supervisors.

The fact that bonds maturing before 2016 were explicitly excluded from BRRD bail-in provides a unique opportunity to overcome the usual identification challenge, as it allows to study the effect of the BRRD on debt holders' perception of implicit guarantees within banks. Banks' riskiness is fully accounted for by including bank $\times$ month fixed effects. Therefore the regressions only pick up effects that are related to investors' changing their perception of the likelihood that a particular bond will be bailed-in, in case of a bank failure (and not the (possibly changing) likelihood of a bank failure itself). This enables me to establish a causal link between a change in the regulators ability to bail-in creditors (which 
affects only a sub set of the outstanding liabilities) and their response in regard to market prices of applicable securities, independent of the banks' risk profile.

They key finding based on 26,890 observations for 1491 bonds issued by 53 banks domiciled in 14 European countries illustrates that investors perceive the BRRD bail-in to be a credible threat. On a more fundamental level, this demonstrates their ability to not only monitor the riskiness of the banking sector, but also take into accounting confounding factors such as public guarantees. While before the BRRD there was no statistically significant difference between bonds maturing in 2015 and 2016 in terms of their yields spreads, there is a positive and significant difference after the BRRD was passed. Consistent with theory, the average treated bond in my main sample increases its yield spread by about 10 basis points compared to the control group, since investors understand the likelihood of being bailed-in in case of bank failure increased. The bail-in premium is mainly driven by the banks' equity level. As the changes in the likelihood to be bailed-in in my paper are plausibly exogenous, my inference remains valid across a battery of robustness checks.

I conclude by pointing out the benefits of capitalizing on my identification strategy. The advantage of the set-up lies in the fact that one is able to estimate effects within bank. This allows including bank $\times$ month fixed effects, differencing out any unobserved heterogeneity. Treatment effects are therefore simply measured as the difference between yields spreads of bonds that are subject to bail-in before and after the introduction of the BRRD. My empirical results demonstrate that (a) bond holders are able to monitor bank risks and (b) believe that the BRRD is an improvement in resolution technology making future bail-ins more likely. It remains unexplored whether debt holders acted on the updated regulation and actively influenced the banks' managements risk taking, which appears a promising area for future research. 


\section{References}

Acharya, Viral V. and Tanju Yorulmazer (2007). "Too many to fail-An analysis of time-inconsistency in bank closure policies". In: Journal of Financial Intermediation 16.1, pp. 1-31.

Admati, Anat R. et al. (2013). "Fallacies, Irrelevant Facts, and Myths in the Discussion of Capital Regulation: Why Bank Equity is Not Socially Expensive". In: Standford Buisness School Working Paper 2065.

Alexander, Kern (2013). "Bank resolution and recovery in the EU: Enhancing banking union?" In: ERA Forum 14.1, pp. 81-93.

Angrist, Joshua David and Jörn-Steffen Pischke (2009). Mostly harmless econometrics: An empiricist's companion / Joshua D. Angrist E Jörn-Steffen Pischke. Princeton, N.J. and Oxford: Princeton University Press.

Archarya, Viral V., A. Joseph Warburton, and Deniz Anginer (2016). "The End of Market Discipline? Investor Expectations of Implicit State Guarantees”. In: NYU Working Paper.

Ashcraft, Adam B. (2008). "Does the market discipline banks? New evidence from regulatory capital mix". In: Journal of Financial Intermediation 17.4, pp. 543561.

Autor, David H. (2003). "Outsourcing at Will: The Contribution of Unjust Dismissal Doctrine to the Growth of Employment Outsourcing". In: Journal of Labor Economics 21.1, pp. 1-42.

Bennett, Rosalind L., Vivian Hwa, and Myron L. Kwast (2015). "Market discipline by bank creditors during the 2008-2010 crisis". In: Journal of Financial Stability 20, pp. 51-69.

Billett, Matthew T., Jon A. Garfinkel, and Edward S. O’Neal (1998). “The cost of market versus regulatory discipline in banking". In: Journal of Financial Economics 48.3, pp. 333-358. 
Binder, John J. (1985). "Measuring the Effects of Regulation with Stock Price Data". In: The RAND Journal of Economics 16.2, p. 167.

Black, Lamont K. and Lieu N. Hazelwood (2013). "The effect of TARP on bank risk-taking”. In: Journal of Financial Stability 9.4, pp. 790-803.

Bliss, Robert and Flannery (2002). "Market Discipline in the Governance of U.S. Bank Holding Companies: Monitoring vs. Influencing". In: Review of Finance 6.3, pp. 361-396.

Boermans, Martijn and Sweder van Wijnbergen (2017). "Contingent convertible bonds: Who invests in European CoCos?" In: DNB Working Paper No. 543.

Brunnermeier, Markus K. et al. (2016). “The Sovereign-Bank Diabolic Loop and ESBies”. In: American Economic Review 106.5, pp. 508-512.

Calomiris, Charles W. (1999). "Building an incentive-compatible safety net". In: Journal of Banking E Finance 23.10, pp. 1499-1519.

Card, David and Alan B. Krueger (2000). "Minimum Wages and Employment: A Case Study of the Fast-Food Industry in New Jersey and Pennsylvania: Reply". In: American Economic Review 90.5, pp. 1397-1420.

Conlon, Thomas and John Cotter (2014). “Anatomy of a bail-in”. In: Journal of Financial Stability 15, pp. 257-263.

Crespi, Fabrizio and Danilo V. Mascia, eds. (2018). Bank Funding Strategies. Cham: Springer International Publishing.

Dam, Lammertjan and Michael Koetter (2012). "Bank Bailouts and Moral Hazard: Evidence from Germany”. In: Review of Financial Studies 25.8, pp. 23432380.

Danisewicz, Piotr et al. (2016). “The real effects of banking supervision: Evidence from enforcement actions". In: Journal of Financial Intermediation.

DeYoung, Robert, Michal Kowalik, and Jack Reidhill (2013). "A theory of failed bank resolution: Technological change and political economics". In: Journal of Financial Stability 9.4, pp. 612-627. 
Dimitrios, Anastasiou, Louri Helen, and Tsionas Mike (2016). "Determinants of non-performing loans: Evidence from Euro-area countries". In: Finance Research Letters 18, pp. 116-119.

Duchin, Ran and Denis Sosyura (2014). "Safer ratios, riskier portfolios: Banks response to government aid". In: Journal of Financial Economics 113.1, pp. 128.

European Parliament (25/04/2014). Banking Recovery and Resolution Directive: BRRD.

Farhi, Emmanuel and Jean Tirole (2012). "Collective Moral Hazard, Maturity Mismatch, and Systemic Bailouts". In: American Economic Review 102.1, pp. 6093.

Flannery, Mark J. and Sorin M. Sorescu (1996). "Evidence of Bank Market Discipline in Subordinated Debenture Yields: 1983-1991". In: The Journal of Finance 51.4, pp. 1347-1377.

Goldberg, Lawrence G. and Sylvia C. Hudgins (2002). "Depositor discipline and changing strategies for regulating thrift institutions". In: Journal of Financial Economics 63.2, pp. 263-274.

Hadjiemmanuil, C. (2015). "Bank Resolution Financing in the Banking Union". In: Society and Economy Working Papers 6.

Hakenes, Hendrik and Isabel Schnabel (2010). "Banks without parachutes: Competitive effects of government bail-out policies". In: Journal of Financial Stability 6.3, pp. 156-168.

Hasan, Iftekhar, Akhtar Siddique, and Xian Sun (2015). "Monitoring the "invisible" hand of market discipline: Capital adequacy revisited". In: Journal of Banking E Finance 50, pp. 475-492.

Hett, Florian and Alexander Schmidt (2017). "Bank rescues and bailout expectations: The erosion of market discipline during the financial crisis". In: Journal of Financial Economics 126.3, pp. 635-651. 
Hüser, Anne-Caroline et al. (2017). "The systemic implications of bail-in: a multilayered network approach". In: ECB Working Paper No 2010.

Ignatowski, Magdalena and Josef Korte (2014). "Wishful thinking or effective threat? Tightening bank resolution regimes and bank risk-taking". In: Journal of Financial Stability 15, pp. 264-281.

Imbens, Guido and Jeffrey Wooldridge (2008). Recent Developments in the Econometrics of Program Evaluation. Cambridge, MA: National Bureau of Economic Research.

Jagtiani, Julapa, George Kaufman, and Catharine Lemieux (2002). "The Effect of Credit Risk on Bank and Bank Holding Company Bond Yields: Evidence from the Post-FDICIA Period”. In: Journal of Financial Research 25.4, pp. 559-575.

Jordà, Òscar et al. (2017). Bank Capital Redux: Solvency, Liquidity, and Crisis. Cambridge, MA: National Bureau of Economic Research.

Keeley, Michael C. (1990). “Deposit Insurance, Risk, and Market Power in Banking”. In: American Economic Review 80.5, pp. 1183-1200.

Kelly, Bryan, Hanno Lustig, and Stijn van Nieuwerburgh (2016). "Too-Systemicto-Fail: What Option Markets Imply about Sector-Wide Government Guarantees". In: American Economic Review 106.6, pp. 1278-1319.

Longstaff, Francis, Sanjay Mithal, and Eric Neis (2005). “Corporate Yield Spreads: Default Risk or Liquidity? New Evidence from the Credit Default Swap Market”. In: The Journal of Finance 60.5, pp. 2213-2253.

Martinez Peria, Maria Soledad and Sergio L. Schmukler (2001). "Do Depositors Punish Banks for Bad Behavior? Market Discipline, Deposit Insurance, and Banking Crises". In: The Journal of Finance 56.3, pp. 1029-1051.

Papanikolaou, Nikolaos I. (2018). "To be bailed out or to be left to fail? A dynamic competing risks hazard analysis”. In: Journal of Financial Stability 34, pp. 6185. 
Philippon, Thomas and Aude Salord (2017). Bail-ins and Bank Resolution in Europe: A Progress Report.

Raffaele Giuliana (2018). “Impact of Bail-In on Banks' Bond Yields and Market Discipline". In: Working paper.

Schäfer, Alexander, Isabel Schnabel, and Beatrice Di Weder Mauro (2016). Bail-In Expectations for European Banks: Actions Speak Louder than Words.

Schich, Sebastian and Sofia Lindh (2012). "Implicit guarantees for bank debt: where do we stand?" In: OECD Journal: Financial Market Trends 2012/1.

Sironi, Andrea (2003). "testing for Market Discipline in the European Banking Industry: Evidence from Subordinated Debt Issues”. In: Journal of Money, Credit and Banking 35, pp. 443-472.

Svenson, Lars (1995). "Estimating and Interpreting Forward Interest Rates: Sweden 1992 - 1994". In: Sveriges Riksbank Quarterly Review 3, pp. 13-26.

Tröger, Tobias H. (2018). “Too Complex to Work: A Critical Assessment of the Bail-in Tool under the European Bank Recovery and Resolution Regime”. In: Journal of Financial Regulation 4.1, pp. 35-72.

Walther, Ansgar and White Lucy (2015). "Rules versus discretion in bank resolution". In: Working paper. 


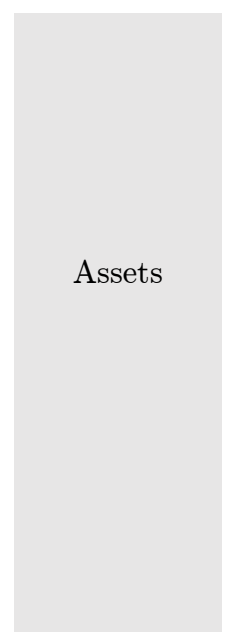

Assets

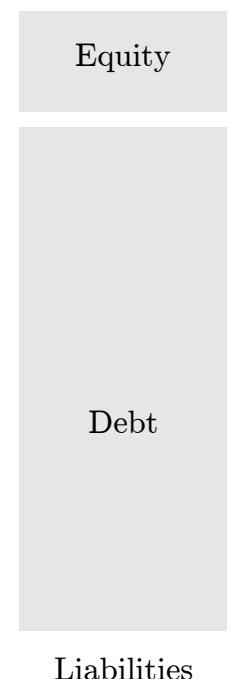

(1)

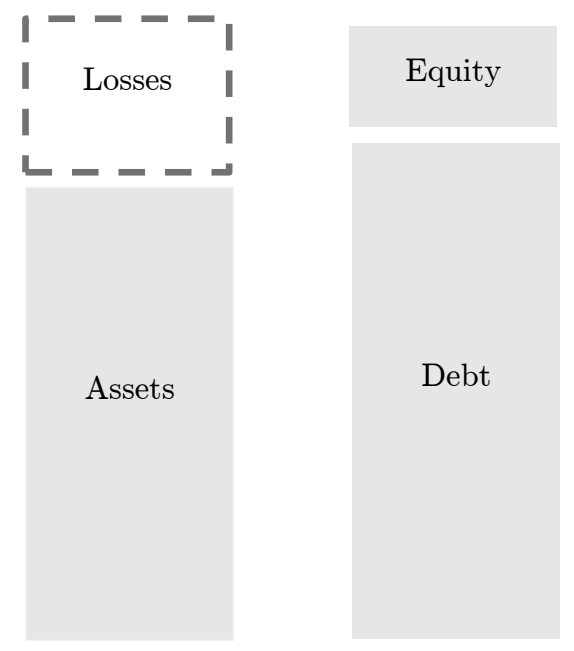

Liabilities

(2)

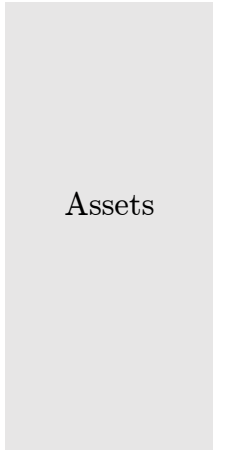

Assets

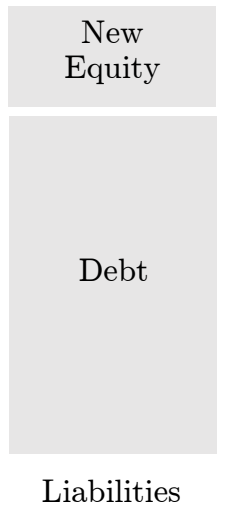

(4)

(3)

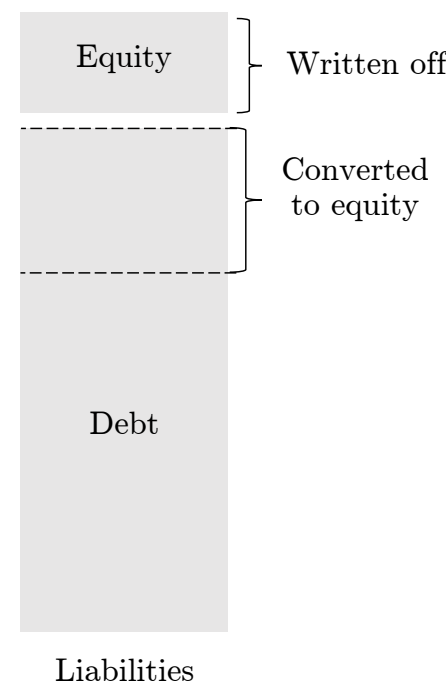

Figure 2: How the bail-in tool works

This graphs demonstrates how the bail-in tool can be used to recapitalize banks in distress. In plot (1) a stylized bank balance sheet is depicted. If the banks' assets turn out to be less worth than originally thought, equity (as residual claim on the assets) will be reduced until the bank is bankrupt (as in (2)). If raising new equity is not possibly and no private sector M\&A solution can be brokered, the resolution authorities had to either let the bank fail and had it enter bankruptcy procedures (risking negative externalities on both financial markets and the real economy) or had to taxpayer money to fund a bailout. The BRRD provides a new option by writing off equity and convert outstanding debt into new equity as depicted in plot (3). By artificially recapitalizing the bank through writing off existing debt, the losses on the balance sheet can be compensated and neither a (potentially socially costly) bankruptcy nor a publicly funded bailout are necessary. 
Table 1: Summary statistics

This table presents the summary statistics of the main sample. Panel A describes the yield data. The pretreatment period is June 2011 to May 2012. The post treatment period is April 2014 - March 2015. Bonds maturing before 01/01/2016 are in the control group. Bonds maturing between 01/01/2016 and 31/12/2016 are in the treatment group. Panel B describes the balance sheet data used for sample splits and interactions. The values are the 2010-2012 average of the respective variables.

\begin{tabular}{|c|c|c|c|c|c|c|c|c|}
\hline \multicolumn{9}{|c|}{ Panel A: Bond Data (Bloomberg) } \\
\hline & $\mathrm{N}$ & Mean & $\mathrm{Sd}$ & Min & P1 & P50 & P99 & Max \\
\hline \multicolumn{9}{|l|}{ Banks } \\
\hline Yield (in \% points) & 26,686 & 2.37 & 1.72 & 0.02 & 0.18 & 1.75 & 6.64 & 8.68 \\
\hline Yield Spread (in \% points) & 26,686 & 1.76 & 1.17 & 0.00 & 0.27 & 1.45 & 5.36 & 7.57 \\
\hline Remaining Life (Months) & 26,686 & 37.36 & 23.32 & 0 & 1 & 37 & 94 & 102 \\
\hline \multicolumn{9}{|l|}{ Corporates } \\
\hline Yield (in \% points) & 4,534 & 1.98 & 1.51 & 0.04 & .09 & 1.66 & 5.92 & 7.69 \\
\hline Yield Spread (in \% points) & 4,534 & 1.41 & 1.04 & 0.02 & .17 & 1.10 & 4.80 & 7.65 \\
\hline Remaining Life (Months) & 4,534 & 34 & 22.44 & 0 & 1 & 35 & 95 & 101 \\
\hline \multicolumn{9}{|c|}{ Yield Spread by groups in \% points (Banks) } \\
\hline & & & \multicolumn{2}{|c|}{$\begin{array}{c}\text { non-treated } \\
\text { (maturing 2015) }\end{array}$} & \multicolumn{4}{|c|}{$\begin{array}{c}\text { treated } \\
\text { (maturing 2016-2019) }\end{array}$} \\
\hline \multicolumn{3}{|c|}{$\begin{array}{l}\text { Pre-treatment period } \\
06 / 06 / 2011-06 / 05 / 2012\end{array}$} & \multicolumn{2}{|c|}{$\begin{array}{c}2.43 \\
(1.31)\end{array}$} & \multicolumn{4}{|c|}{$\begin{array}{c}2.48 \\
(1.37)\end{array}$} \\
\hline \multirow{2}{*}{\multicolumn{3}{|c|}{$\begin{array}{l}\text { Treatment period } \\
15 / 04 / 2014-15 / 03 / 2015\end{array}$}} & \multirow{2}{*}{\multicolumn{2}{|c|}{$\begin{array}{l}1.23 \\
(.72)\end{array}$}} & \multirow{2}{*}{\multicolumn{4}{|c|}{$\begin{array}{l}1.32 \\
(.74)\end{array}$}} \\
\hline & & & & & & & & \\
\hline \multicolumn{9}{|c|}{ Panel B: Balance Sheet Data (SNL) } \\
\hline \multicolumn{9}{|l|}{ Mean in 2010-2012 } \\
\hline \multicolumn{2}{|c|}{ Variable (SNL Key) } & $\mathrm{N}$ & Mean & $\mathrm{Sd}$ & Min & Max & & \\
\hline \multicolumn{2}{|c|}{ Core Tier 1 Ratio (235297) } & 39 & 9.58 & 1.79 & 5.24 & 12.91 & & \\
\hline
\end{tabular}




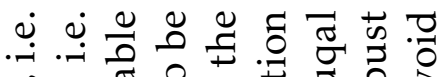

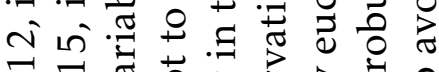

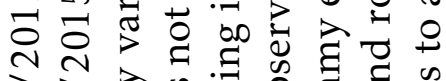

ते 숭.

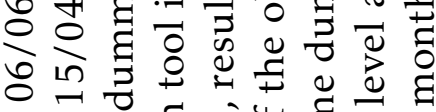

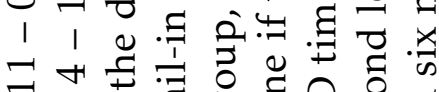

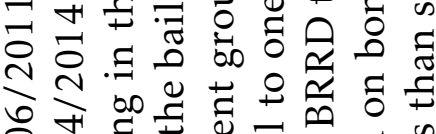

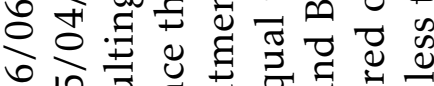

응

क.

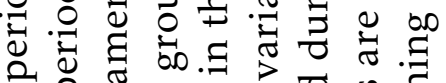

2.

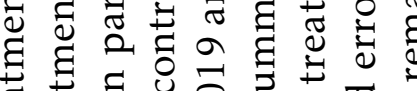

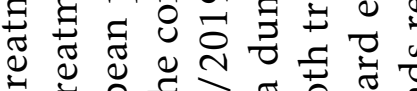

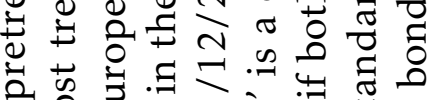

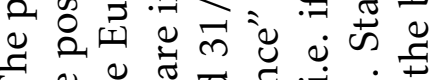

Fै

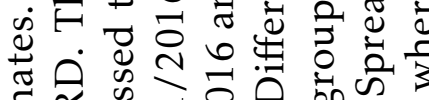

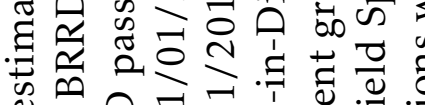

\%

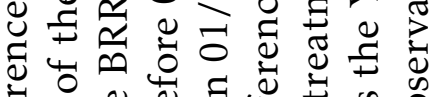

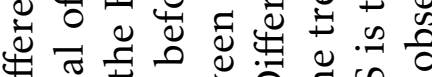

क)

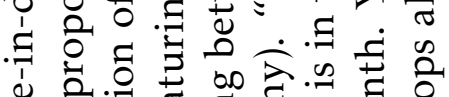

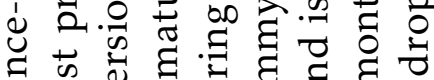

证

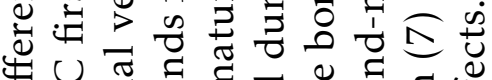

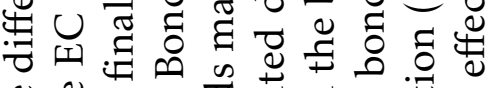

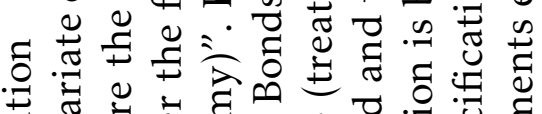

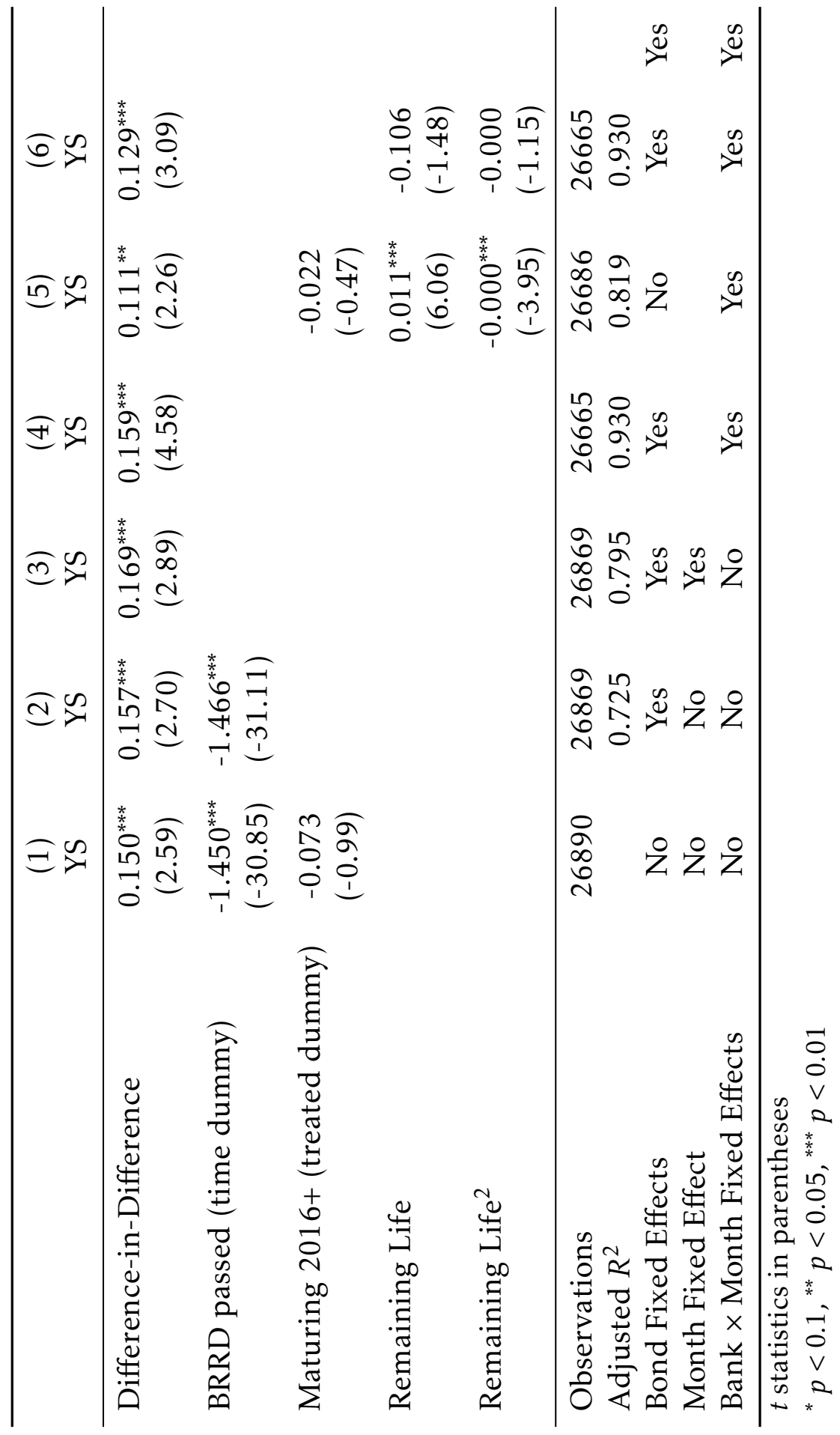




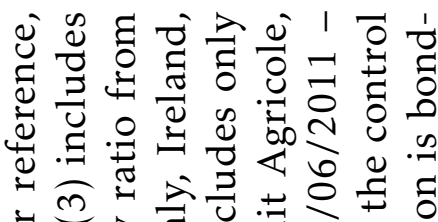

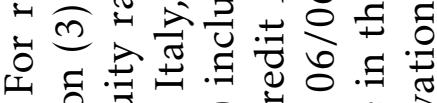
.

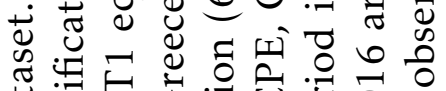

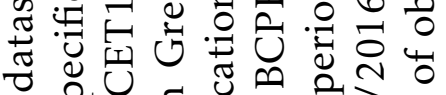
के $\mp \stackrel{0}{=} \stackrel{0}{=}$

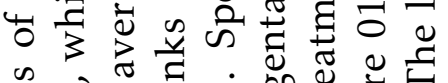

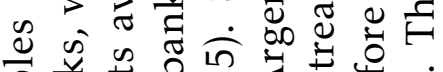

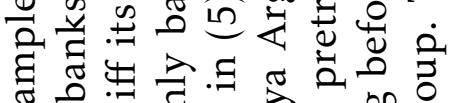

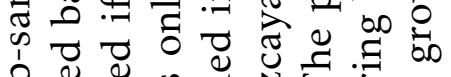

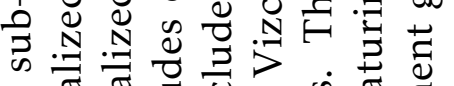

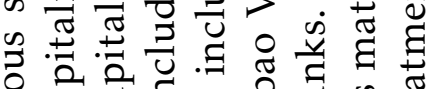

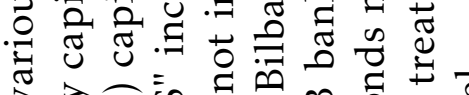

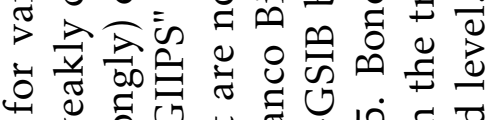

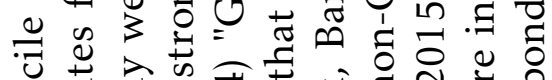

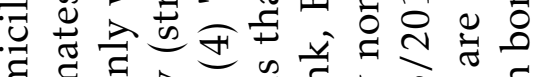
घี छี

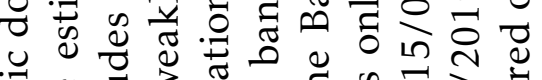

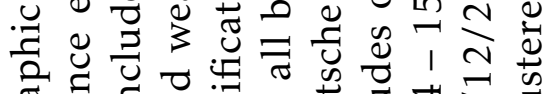

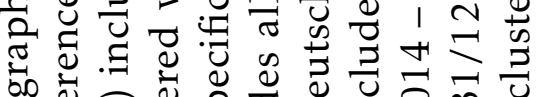
के

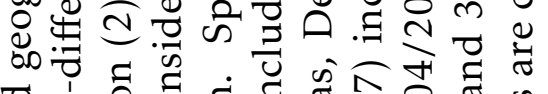
क.

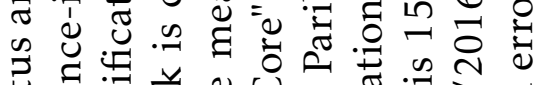

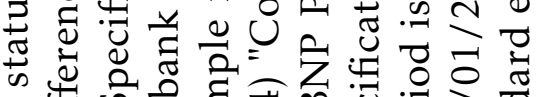

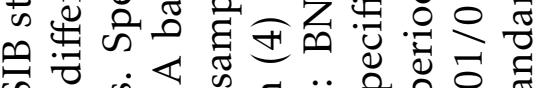
जि

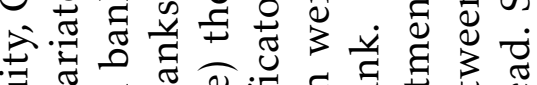

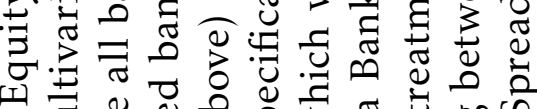

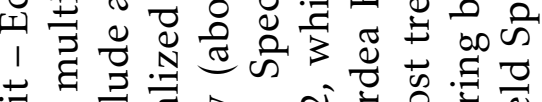

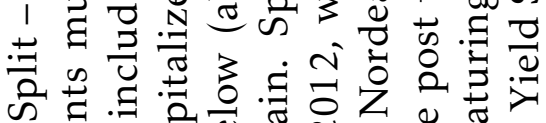
की

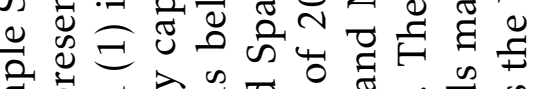
菂 क

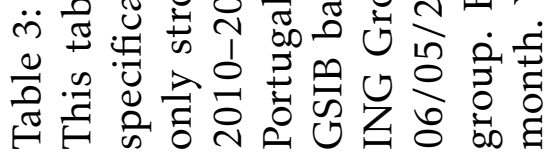

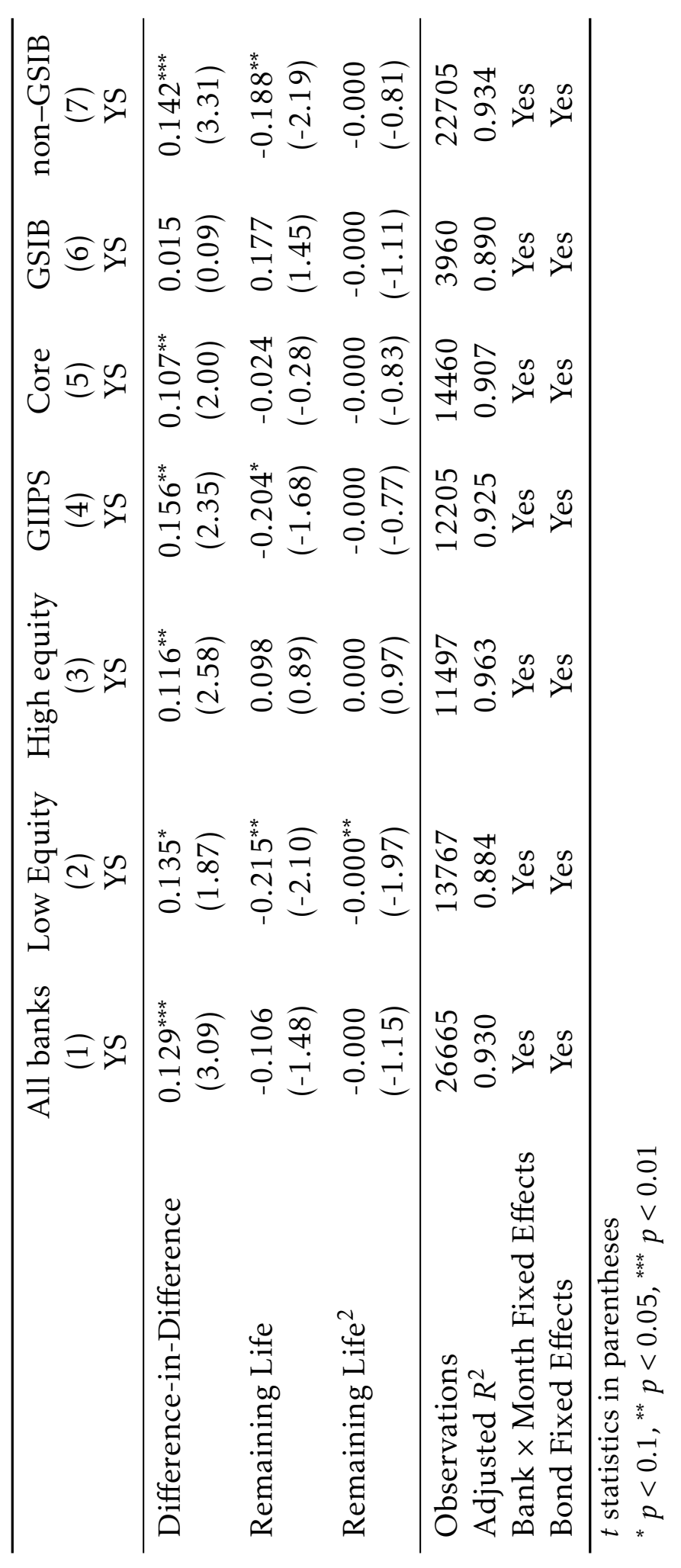


Table 4: Heterogeneous Effects

This table presents multivariate difference-in-difference estimates with additional interaction terms. Specification (1) is the baseline scenario from Table 2 for reference. In specification (2) Bail-in risk is captured by the negative average standardized Core Tier 1 Ratio in 2010-2012 (i.e. less equity implies higher bail-in risk). In specification (3) it is equal to one if the bank is not a GSIB, i.e. neither of BNP Paribas, Deutsche Bank, Banco Bilbao Vizcaya Argentaria, BCPE, Credit Agricole, ING Groep or Nordea Bank. In sepcification (4) it is equal to one if the banks is not headquartered in Greece, Italy, Ireland, Portugal or Spain. The pretreatment period is 06/06/2011-06/05/2012. The post treatmentperiod is $15 / 04 / 2014-15 / 03 / 2015$. Bonds maturing before $01 / 01 / 2016$ are in the control group. Bonds maturing between $01 / 01 / 2016$ and 31/12/2019 are in the treatment group. The level of observation is bond-month. YS is the Yield Spread. Standard errors are clustered on bond level.

\begin{tabular}{lcccc}
\hline & $(1)$ & $(2)$ & $(3)$ & $(4)$ \\
& YS & YS & YS & YS \\
\hline Difference-in-Difference & $0.129^{* * *}$ & $0.119^{* * *}$ & 0.083 & $0.105^{* *}$ \\
& $(3.09)$ & $(2.76)$ & $(0.69)$ & $(2.08)$ \\
Difference-in-Difference $\times(-C E T 1)$ & & $0.166^{* * *}$ & & \\
& & $(3.50)$ & & \\
Difference-in-Difference $\times$ non-GSIB & & & 0.051 & \\
& & & $(0.42)$ & \\
Difference-in-Difference $\times$ GIIPS & & & & 0.056 \\
& & & & $(0.80)$ \\
Remaining Life & -0.106 & -0.101 & -0.106 & -0.106 \\
& $(-1.48)$ & $(-1.28)$ & $(-1.48)$ & $(-1.48)$ \\
Remaining Life & & & & \\
& -0.000 & -0.000 & -0.000 & -0.000 \\
& $(-1.15)$ & $(-1.27)$ & $(-1.17)$ & $(-1.12)$ \\
\hline Observations & 26665 & 24912 & 26665 & 26665 \\
Adjusted $R^{2}$ & 0.930 & 0.929 & 0.930 & 0.930 \\
Bank $\times$ Month Fixed Effects & Yes & Yes & Yes & Yes \\
Bond Fixed Effects & Yes & Yes & Yes & Yes \\
\hline
\end{tabular}

$t$ statistics in parentheses

${ }^{*} p<0.1,{ }^{* *} p<0.05,{ }^{* * *} p<0.01$ 
Table 5: Parallel Trends Test for the Banking Sector

This table presents the result of a standard parallel trends test. The level of observation is bond-month. The regressors $\mathrm{m} 13, \ldots, \mathrm{m} 1$ are differen-in-difference lags, the regressor $\mathrm{p} 1, \ldots, \mathrm{p} 12$ are difference-in-difference leads. The pretreatment period is $06 / 06 / 2011-06 / 05 / 2012$. The post treatmentperiod is $15 / 04 / 2014-$ $15 / 03 / 2015$. Bonds maturing before $01 / 01 / 2016$ are in the control group. Bonds maturing between $01 / 01 / 2016$ and 31/12/2019 are in the treatment group. Standard errors are clustered on bond level.

\begin{tabular}{|c|c|c|c|c|}
\hline \multirow[b]{2}{*}{ m12 (2011m06) } & \multicolumn{2}{|c|}{$\begin{array}{c}\text { (1) } \\
\text { Yield Spread }\end{array}$} & \multicolumn{2}{|c|}{$\begin{array}{c}\text { (2) } \\
\text { Yield Spread }\end{array}$} \\
\hline & 0.043 & $(0.91)$ & 0.011 & $(0.26)$ \\
\hline m11 (2011m07) & 0.026 & $(0.55)$ & 0.010 & $(0.24)$ \\
\hline m10 (2011m08) & 0.039 & $(0.84)$ & 0.008 & $(0.21)$ \\
\hline m09 (2011m09) & $0.091^{*}$ & $(1.93)$ & $0.070^{*}$ & $(1.88)$ \\
\hline m08 (2011m10) & 0.052 & $(1.40)$ & 0.050 & $(1.46)$ \\
\hline m07 (2011m11) & 0.048 & $(1.24)$ & 0.050 & $(1.40)$ \\
\hline m06 (2011m12) & -0.003 & $(-0.08)$ & 0.001 & $(0.02)$ \\
\hline m05 (2012m01) & $-0.053^{*}$ & $(-1.75)$ & -0.035 & $(-1.24)$ \\
\hline m04 (2012m02) & -0.007 & $(-0.30)$ & 0.009 & $(0.38)$ \\
\hline m03 (2012m03) & $-0.056^{* * *}$ & $(-2.80)$ & $-0.057^{* * *}$ & $(-3.04)$ \\
\hline m02 (2012m04) & $-0.070^{* * *}$ & $(-4.22)$ & $-0.066^{* * *}$ & $(-4.31)$ \\
\hline \multicolumn{5}{|l|}{ m01 (2012m05), ommitted } \\
\hline p01 (2014m04) & $0.093^{*}$ & $(1.86)$ & $0.114^{* * * *}$ & $(2.63)$ \\
\hline p02 (2014m05) & $0.098^{*}$ & $(1.90)$ & $0.119^{* * *}$ & $(2.64)$ \\
\hline p03 (2014m06) & 0.071 & (1.36) & $0.100^{* *}$ & $(2.20)$ \\
\hline p04 (2014m07) & $0.117^{* *}$ & $(2.21)$ & $0.142^{* * *}$ & $(3.11)$ \\
\hline p05 (2014m08) & $0.126^{* *}$ & $(2.37)$ & $0.155^{* * *}$ & $(3.39)$ \\
\hline p06 (2014m09) & $0.110^{* *}$ & $(2.12)$ & $0.140^{* * *}$ & $(3.08)$ \\
\hline p07 (2014m10) & $0.100^{*}$ & $(1.92)$ & $0.126^{* * *}$ & $(2.77)$ \\
\hline p08 (2014m11) & $0.131^{* *}$ & $(2.51)$ & $0.126^{* * *}$ & $(2.75)$ \\
\hline p09 (2014m12) & $0.143^{* * *}$ & $(2.75)$ & $0.142^{* * *}$ & $(3.05)$ \\
\hline p10 (2015m01) & $0.153^{* * *}$ & $(2.93)$ & $0.147^{* * *}$ & $(3.09)$ \\
\hline p11 (2015m02) & $0.100^{*}$ & $(1.88)$ & $0.098^{* *}$ & $(2.00)$ \\
\hline p12 (2015m03) & 0.088 & $(1.62)$ & $0.093^{*}$ & $(1.86)$ \\
\hline Treated Dummy & -0.025 & $(-0.49)$ & & \\
\hline Remaining Life & $0.011^{* * *}$ & $(6.04)$ & -0.107 & $(-1.48)$ \\
\hline Remaining Life ${ }^{2}$ & $-0.000^{* * *}$ & $(-3.94)$ & -0.000 & $(-1.24)$ \\
\hline Observations & \multicolumn{2}{|c|}{26474} & \multicolumn{2}{|c|}{26474} \\
\hline $\begin{array}{l}\text { Bank } \times \text { Month } \\
\text { Fixed Effects }\end{array}$ & \multicolumn{2}{|c|}{ Yes } & \multicolumn{2}{|c|}{ Yes } \\
\hline Bond Fixed Effects & \multicolumn{2}{|c|}{ No } & \multicolumn{2}{|c|}{ Yes } \\
\hline
\end{tabular}

$t$ statistics in parentheses

${ }^{*} p<0.1,{ }^{* *} p<0.05,{ }^{* * *} p<0.01$ 
Table 6: Corporates Bond Sample

This table presents multivariate difference-in-difference estimates for the nonbank corporate bond sample. The pretreatment period is 06/06/2011 $06 / 06 / 2012$. The post treatmentperiod is $15 / 04 / 2014-15 / 03 / 2015$. Bonds maturing before $01 / 01 / 2016$ are in the control group. Bonds maturing between $01 / 01 / 2016$ and 31/12/2019 are in the treatment group. The level of observation is bond-month. YS is the Yield Spread. Standard errors are clustered on bond level.

\begin{tabular}{|c|c|c|c|c|}
\hline & \multirow{3}{*}{$\begin{array}{l}(1) \\
\text { YS }\end{array}$} & \multirow[b]{2}{*}{ (2) } & \multicolumn{2}{|c|}{$\begin{array}{l}\text { maturing } 2015 \\
\& 2016 \text { only }\end{array}$} \\
\hline & & & (3) & (4) \\
\hline & & YS & YS & YS \\
\hline Difference-in-Difference & $\begin{array}{l}-0.098 \\
(-0.68)\end{array}$ & $\begin{array}{l}-0.013 \\
(-0.11)\end{array}$ & $\begin{array}{l}-0.157 \\
(-1.04)\end{array}$ & $\begin{array}{l}0.122 \\
(0.96)\end{array}$ \\
\hline Treated dummy & $\begin{array}{l}-0.029 \\
(-0.22)\end{array}$ & & & \\
\hline Remaining Life & $\begin{array}{c}0.026^{* * *} \\
(4.18)\end{array}$ & $\begin{array}{l}0.240 \\
(0.69)\end{array}$ & $\begin{array}{l}-0.019 \\
(-0.09)\end{array}$ & $\begin{array}{l}-0.153 \\
(-0.83)\end{array}$ \\
\hline Remaining Life ${ }^{2}$ & $\begin{array}{c}-0.000^{* * *} \\
(-3.11)\end{array}$ & $\begin{array}{c}-0.000^{* * *} \\
(-3.65)\end{array}$ & $\begin{array}{l}-0.000^{* *} \\
(-2.07)\end{array}$ & \\
\hline Observations & 4534 & 4534 & 3352 & 3352 \\
\hline Adjusted $R^{2}$ & 0.906 & 0.947 & 0.949 & 0.947 \\
\hline Company $\times$ Month Fixed Effects & Yes & Yes & Yes & Yes \\
\hline Bond Fixed Effects & No & Yes & Yes & Yes \\
\hline
\end{tabular}

$t$ statistics in parentheses

${ }^{*} p<0.1,{ }^{* *} p<0.05,{ }^{* * *} p<0.01$ 
Table 7: Parallel Trends Test for the Corporate Sector

This table presents the result of a standard parallel trends test for the nonbank corporate sample. The level of observation is bond-month. The regressors $\mathrm{m} 13, \ldots, \mathrm{m} 1$ are differen-in-difference lags, the regressor $\mathrm{p} 1, \ldots, \mathrm{p} 12$ are difference-in-difference leads. The pretreatment period is $06 / 06 / 2011-$ $06 / 05 / 2012$. The post treatmentperiod is $15 / 04 / 2014-15 / 03 / 2015$. Bonds maturing before $01 / 01 / 2016$ are in the control group. Bonds maturing between $01 / 01 / 2016$ and $31 / 12 / 2019$ are in the treatment group. Standard errors are clustered on bond level.

\begin{tabular}{|c|c|c|c|c|}
\hline \multirow[b]{2}{*}{ m12 (2011m06) } & \multicolumn{2}{|c|}{$\begin{array}{c}(1) \\
\text { Yield Spread }\end{array}$} & \multicolumn{2}{|c|}{$\begin{array}{c}(2) \\
\text { Yield Spread }\end{array}$} \\
\hline & 0.210 & $(1.32)$ & 0.110 & $(0.88)$ \\
\hline m11 (2011m07) & 0.135 & $(0.94)$ & 0.082 & $(0.68)$ \\
\hline m10 (2011m08) & 0.033 & $(0.26)$ & -0.015 & $(-0.13)$ \\
\hline m09 (2011m09) & 0.027 & $(0.21)$ & 0.023 & $(0.20)$ \\
\hline m08 (2011m10) & 0.078 & $(0.66)$ & 0.070 & $(0.69)$ \\
\hline m07 (2011m11) & 0.071 & $(0.65)$ & 0.065 & $(0.69)$ \\
\hline m06 (2011m12) & -0.014 & $(-0.09)$ & -0.022 & $(-0.15)$ \\
\hline m05 (2012m01) & 0.026 & $(0.25)$ & -0.000 & $(-0.00)$ \\
\hline $\mathrm{m} 04(2012 \mathrm{~m} 02)$ & 0.034 & $(0.35)$ & 0.002 & $(0.03)$ \\
\hline m03 (2012m03) & 0.083 & $(0.78)$ & -0.018 & $(-0.36)$ \\
\hline $\mathrm{m} 02(2012 \mathrm{~m} 04)$ & 0.069 & $(0.70)$ & -0.007 & $(-0.17)$ \\
\hline \multicolumn{5}{|c|}{ m01 (2012m05), ommitted } \\
\hline p01 (2014m04) & 0.019 & $(0.13)$ & 0.061 & $(0.48)$ \\
\hline p02 (2014m05) & -0.071 & $(-0.46)$ & -0.030 & $(-0.24)$ \\
\hline p03 (2014m06) & -0.054 & $(-0.36)$ & -0.015 & $(-0.12)$ \\
\hline p04 (2014m07) & 0.010 & $(0.07)$ & 0.045 & $(0.35)$ \\
\hline p05 (2014m08) & 0.043 & $(0.28)$ & 0.077 & $(0.58)$ \\
\hline p06 (2014m09) & -0.008 & $(-0.05)$ & 0.031 & $(0.23)$ \\
\hline p07 (2014m10) & 0.014 & $(0.09)$ & 0.051 & $(0.40)$ \\
\hline p08 (2014m11) & 0.004 & $(0.02)$ & 0.041 & $(0.31)$ \\
\hline p09 (2014m12) & -0.034 & $(-0.21)$ & 0.002 & $(0.01)$ \\
\hline $\mathrm{p} 10(2015 \mathrm{~m} 01)$ & -0.106 & $(-0.63)$ & -0.056 & $(-0.40)$ \\
\hline p11 (2015m02) & -0.218 & $(-1.06)$ & -0.140 & $(-0.80)$ \\
\hline p12 (2015m03) & -0.278 & $(-0.99)$ & -0.226 & $(-0.96)$ \\
\hline Treated dummy & -0.086 & $(-0.59)$ & & \\
\hline Remaining Life & $0.026^{* * *}$ & $(4.29)$ & 0.177 & $(0.57)$ \\
\hline Remaining Life $^{2}$ & $-0.000^{* * *}$ & $(-3.18)$ & $-0.000^{* * *}$ & $(-3.70)$ \\
\hline Observations & \multicolumn{2}{|c|}{4,537} & \multicolumn{2}{|c|}{4,537} \\
\hline $\begin{array}{l}\text { Company } \times \text { Month } \\
\text { Fixed Effects }\end{array}$ & \multicolumn{2}{|c|}{ Yes } & \multicolumn{2}{|l|}{ Yes } \\
\hline Bond Fixed Effects & \multicolumn{2}{|c|}{ No } & \multicolumn{2}{|l|}{ Yes } \\
\hline
\end{tabular}


Table 8: Robustness Check: MREL Equilibrium Pricing This table presents multivariate difference-in-difference estimates. The pretreatment period is $06 / 06 / 2011-06 / 05 / 2012$. The post treatmentperiod is $15 / 04 / 2014-15 / 03 / 2015$. Bonds maturing before $01 / 01 / 2016$ are in the control group. Bonds maturing between 01/01/2016 and 31/12/2016 are in the treatment group. The level of observation is bond-month. YS is the Yield Spread. Specification (1) includes all bonds (maturing up to 31/12/2019) for reference. Standard errors are clustered on bond level.

\begin{tabular}{|c|c|c|c|c|c|}
\hline & \multirow{3}{*}{$\begin{array}{l}\text { (1) } \\
\text { YS }\end{array}$} & \multicolumn{4}{|c|}{2015 vs. 2016 only } \\
\hline & & (2) & (3) & (4) & (5) \\
\hline & & YS & YS & YS & YS \\
\hline Difference-in-Difference & $\begin{array}{c}0.129^{* * *} \\
(3.09)\end{array}$ & $\begin{array}{c}0.161^{* * *} \\
(3.74)\end{array}$ & $\begin{array}{c}0.111^{* * *} \\
(2.99)\end{array}$ & $\begin{array}{c}0.082^{* *} \\
(1.97)\end{array}$ & $\begin{array}{l}0.045 \\
(0.73)\end{array}$ \\
\hline Maturing 2016+ (treated dummy) & & $\begin{array}{c}-0.104^{*} \\
(-1.75)\end{array}$ & & & \\
\hline Remaining Life & $\begin{array}{l}-0.106 \\
(-1.48)\end{array}$ & $\begin{array}{c}0.010^{* * *} \\
(2.82)\end{array}$ & $\begin{array}{l}0.015 \\
(0.19)\end{array}$ & & $\begin{array}{l}0.038 \\
(0.47)\end{array}$ \\
\hline Remaining Life ${ }^{2}$ & $\begin{array}{l}-0.000 \\
(-1.15)\end{array}$ & & & & $\begin{array}{l}-0.000 \\
(-1.42)\end{array}$ \\
\hline $\log$ (Remaining Life) & & & & $\begin{array}{l}0.053 \\
(1.46)\end{array}$ & \\
\hline Observations & 26665 & 17515 & 17500 & 17500 & 17500 \\
\hline Adjusted $R^{2}$ & 0.930 & 0.835 & 0.934 & 0.934 & 0.934 \\
\hline Bank $\times$ Month Fixed Effects & Yes & Yes & Yes & Yes & Yes \\
\hline Bond Fixed Effects & Yes & No & Yes & Yes & Yes \\
\hline
\end{tabular}

$t$ statistics in parentheses

${ }^{*} p<0.1,{ }^{* *} p<0.05,{ }^{* * *} p<0.01$ 


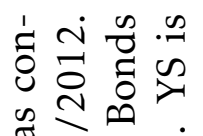

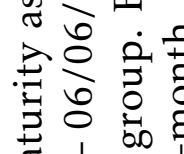

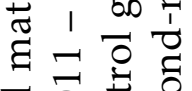

중

o 0

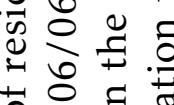

प्र०

車

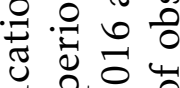

牙艺

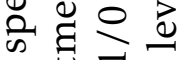

च

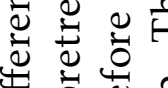

岂岕

bo

क

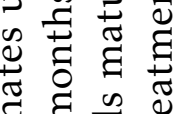

घี छे

क.

过

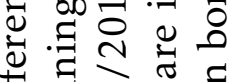

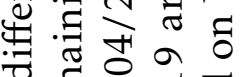

i 린

s

记司吉政

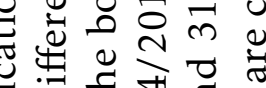

可

Uू. $\frac{2}{0}$ in

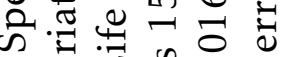

त.

声.

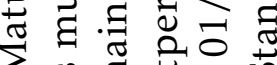

$\sum$ व

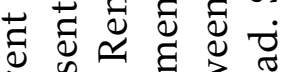

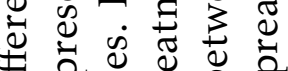

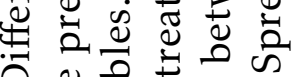

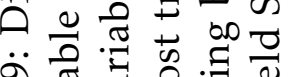

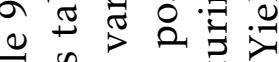

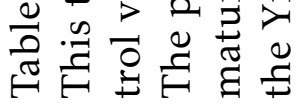

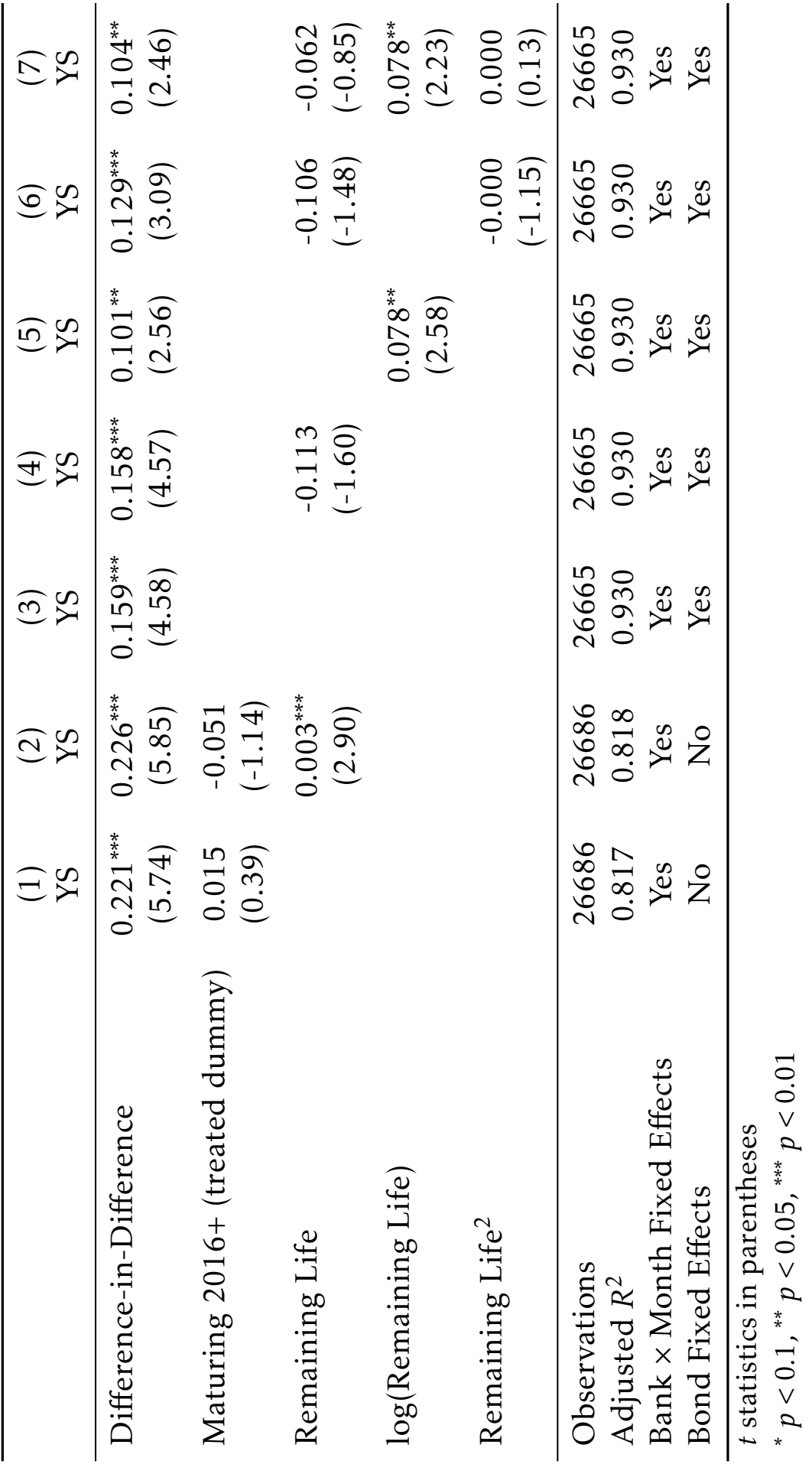

xiii 


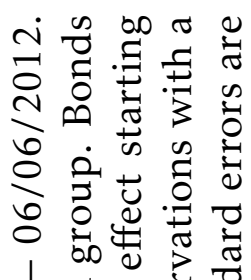

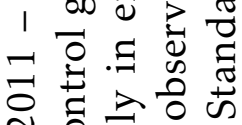

๙ิ

○)

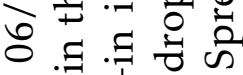

.

ช

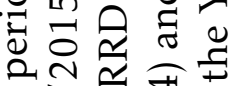

$+\frac{0}{0}$ 我

워요

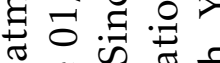

\& क त त्ञ

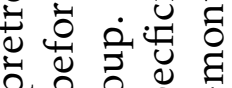

क

$\Xi . \Xi+0$

قี

巳 छ

छ

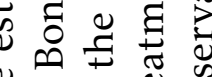

ษ

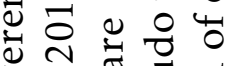

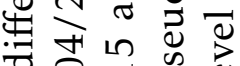

ठำ

$\exists$ เก 워

ष्ठ त

ป

ప

ڤิ

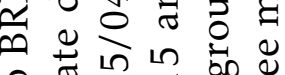

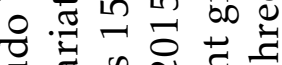

จ $\stackrel{\pi}{2} \frac{\pi}{0}$

ఏీ

मे छ

\& क o $=0$

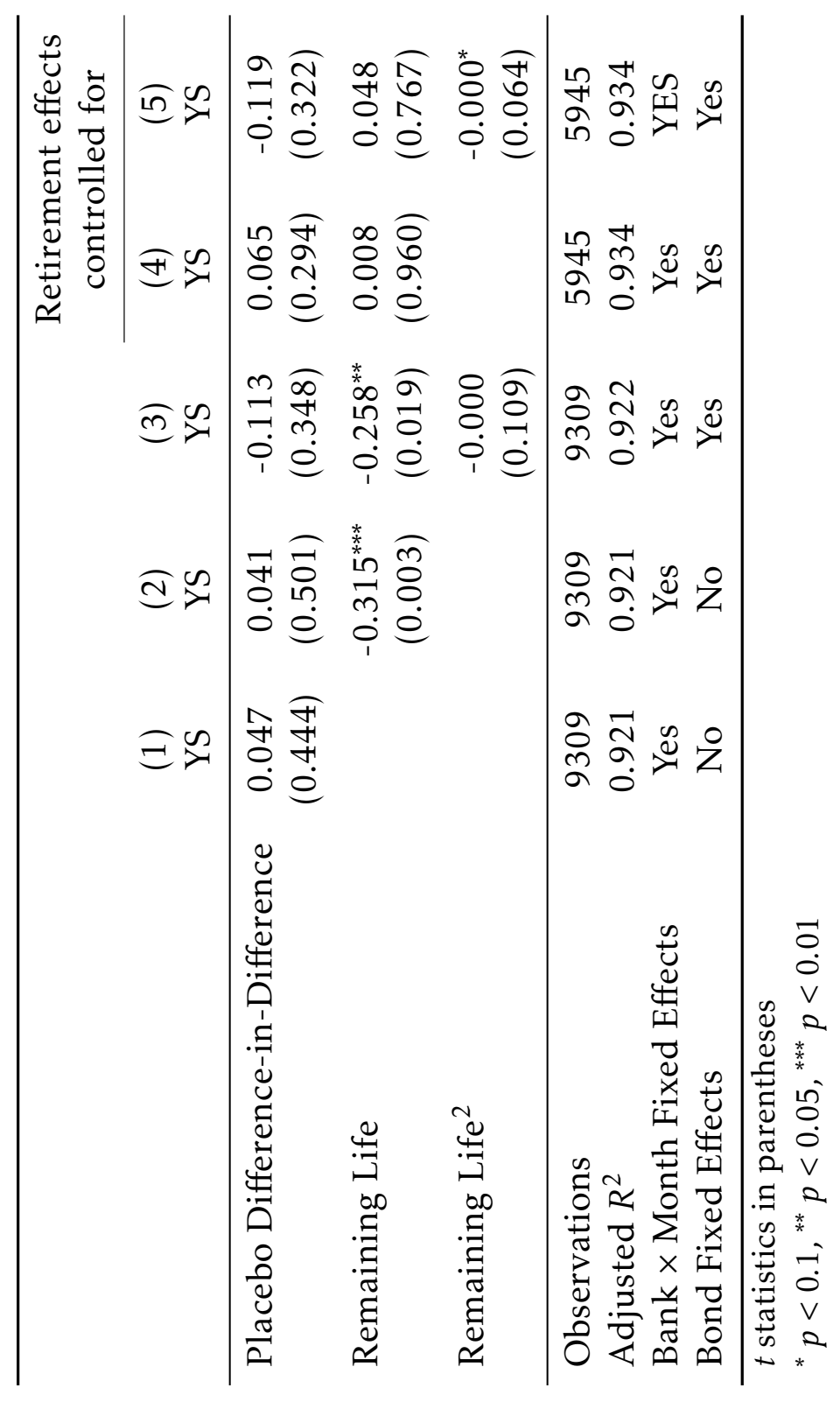

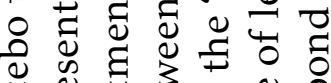

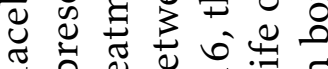

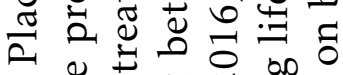

$\because \because \pm$ on

표욜

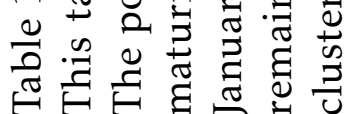

xiv 
Table 11: Parallel Trends Pseudo BRRD

This table presents the result of a standard parallel trends test. The level of observation is bond-month. The regressors $\mathrm{m} 13, \ldots, \mathrm{m} 1$ are differen-in-difference lags, the regressor $\mathrm{p} 1, \ldots, \mathrm{p} 12$ are difference-in-difference leads. The pretreatment period is $06 / 06 / 2011-06 / 06 / 2012$. The post treatmentperiod is $15 / 04 / 2014-$ $15 / 04 / 2015$. Bonds maturing before $31 / 06 / 2015$ are in the control group. Bonds maturing between $01 / 07 / 2015$ and 31/12/2015 are in the treatment group. Since BRRD bail-in is only in effect starting january 2016, the "treatment group" is only a pseudo treatment group. Standard errors are clustered on bond level.

\begin{tabular}{|c|c|c|c|c|}
\hline \multirow[b]{2}{*}{ m12 (2011m06) } & \multicolumn{2}{|c|}{$\begin{array}{c}(1) \\
\text { Yield Spread }\end{array}$} & \multicolumn{2}{|c|}{$\begin{array}{c}(2) \\
\text { Yield Spread }\end{array}$} \\
\hline & $0.120^{*}$ & $(1.76)$ & 0.051 & $(0.77)$ \\
\hline m11 (2011m07) & 0.089 & $(1.31)$ & 0.026 & $(0.40)$ \\
\hline m10 (2011m08) & $0.189^{* *}$ & $(2.36)$ & $0.135^{*}$ & $(1.90)$ \\
\hline m09 (2011m09) & $0.182^{* *}$ & (2.55) & $0.134^{* *}$ & $(2.13)$ \\
\hline m08 (2011m10) & 0.036 & $(0.56)$ & -0.006 & $(-0.10)$ \\
\hline m07 (2011m11) & -0.044 & $(-0.67)$ & -0.080 & $(-1.23)$ \\
\hline m06 (2011m12) & 0.040 & $(0.48)$ & 0.011 & $(0.14)$ \\
\hline m05 (2012m01) & 0.038 & $(0.81)$ & 0.017 & $(0.39)$ \\
\hline m04 (2012m02) & $0.087^{* * * *}$ & $(2.61)$ & $0.070^{* *}$ & $(2.26)$ \\
\hline m03 (2012m03) & $0.056^{* *}$ & $(2.28)$ & $0.043^{*}$ & $(1.87)$ \\
\hline $\mathrm{m} 02(2012 \mathrm{~m} 04)$ & $0.032^{*}$ & $(1.79)$ & 0.025 & $(1.40)$ \\
\hline \multicolumn{5}{|l|}{ m01 (2012m05), ommitted } \\
\hline p01 (2014m04) & -0.048 & $(-0.46)$ & 0.103 & $(1.52)$ \\
\hline p02 (2014m05) & -0.034 & $(-0.32)$ & $0.124^{*}$ & $(1.75)$ \\
\hline p03 (2014m06) & -0.057 & $(-0.52)$ & 0.107 & $(1.51)$ \\
\hline p04 (2014m07) & -0.044 & $(-0.39)$ & $0.126^{*}$ & $(1.80)$ \\
\hline p05 (2014m08) & -0.090 & $(-0.78)$ & 0.087 & $(1.25)$ \\
\hline p06 (2014m09) & -0.070 & $(-0.59)$ & 0.113 & $(1.63)$ \\
\hline p07 (2014m10) & -0.126 & $(-1.04)$ & 0.064 & $(0.94)$ \\
\hline p08 (2014m11) & $-0.214^{*}$ & $(-1.75)$ & -0.019 & $(-0.28)$ \\
\hline p09 (2014m12) & $-0.247^{*}$ & $(-1.96)$ & -0.046 & $(-0.67)$ \\
\hline p10 (2015m01) & -0.176 & $(-1.37)$ & 0.027 & $(0.39)$ \\
\hline p11 (2015m02) & -0.114 & $(-0.88)$ & 0.087 & $(1.15)$ \\
\hline p12 (2015m03) & -0.097 & $(-0.74)$ & 0.099 & $(1.28)$ \\
\hline Remaining Life & $-0.252^{* *}$ & $(-2.25)$ & $-0.317^{* * *}$ & $(-2.90)$ \\
\hline Remaining Life ${ }^{2}$ & $-0.000^{* *}$ & $(-1.99)$ & & \\
\hline Observations & \multicolumn{2}{|c|}{26474} & \multicolumn{2}{|c|}{26474} \\
\hline $\begin{array}{l}\text { Bank } \times \text { Month } \\
\text { Fixed Effects }\end{array}$ & \multicolumn{2}{|c|}{ Yes } & \multicolumn{2}{|c|}{ Yes } \\
\hline Bond Fixed Effects & \multicolumn{2}{|c|}{ No } & \multicolumn{2}{|c|}{ Yes } \\
\hline
\end{tabular}

$t$ statistics in parentheses

${ }^{*} p<0.1,{ }^{* *} p<0.05,{ }^{* * *} p<0.01$ 
Table 12: Data selection process

This table presents the bond sample selection process for the bank bonds used in my analysis.

\begin{tabular}{lrl}
\hline Variable & Filter & Value \\
\hline Issuer Name $^{(1)}$ & INCLUDE & $\begin{array}{l}\text { bank name } \\
\text { "current and subs" } \\
\end{array}$ \\
& "Junior Unsecured", "Sr Unsecured", \\
Payment Rank $^{(2)}$ & INCLUDE & "Jr Subordinated", "Subordinated", "Unsecured" \\
Issue Date $^{(3)}$ & LESS THAN & $06 / 06 / 2012$ \\
Maturity Date $^{(4)}$ & IN RANGE & $01 / 01 / 2015-12 / 30 / 2019$ \\
Maturity Type $^{(5)}$ & INCLUDE & Bullet \\
Currency $^{(6)}$ & INCLUDE & Euro (EUR) \\
\hline
\end{tabular}

Explanation:

(1) The requests above are done for each bank used in Schäfer et al. (2016), except I don't consider Swiss and UK banks. All bonds of the entity and its direct subsidiaries are included. For example for Commerzbank, bonds of Dresdner Bank are also included since Commerzbank acquired Dresdner Bank in 2009. In this respect Dresdner Bank is not considered as a separate bank.

(2) I download all unsecured european bank bonds that are in principle subject to bail-in

(3) Only bonds issued before the reform are considered

(4) Only bonds maturing after the reform was passed are considered.

(5) I include only bullet bonds to avoid distortionary effects of derivatives features as suggested by Archarya et al. (2016)

(6) To be able to compute the yield spread I only use bond yields of Euro denominated bonds.

\section{Yield Curve data}

To compute the yield spread, I first construct the safe yield (spotrate) of a triple A rated Euro denominated government security with residual maturity TTM by fitting the svenson model using the parameters provided by the European Central Bank's Datawarehouse. The keys for the parameters $\beta_{0}, \beta_{1}, \beta_{2}, \beta_{3}, \tau_{1} \& \tau_{2}$ in the warehouse are as follows respectivly: "YC.B.U2.EUR.4F.G_N_A.SV_C_YM.BETA0", "YC.B.U2.EUR.4F.G_N_A.SV_C_YM.BETA2", "YC.B. U2.EUR.4F.G_N_A.SV_C_YM. 
BETA1", "YC.B.U2.EUR.4F.G_N_A.SV_C_YM.BETA3", "YC.B.U2.EUR.4F.G_N_A.SV_

C_ YM.TAU1" and "YC.B.U2.EUR.4F.G_N_A.SV_C_YM.TAU2". If TTM is the term

to maturity (in days), then spotrate $(T T M)=\beta_{0}+\beta_{1} \cdot\left[\frac{1-e^{\frac{-T T M}{\tau_{1}}}}{T T M / \tau_{1}}\right]+\beta_{2} \cdot\left[\frac{1-e^{\frac{-T T M}{\tau_{1}}}}{T T M / \tau_{1}}-e^{\frac{-T T M}{\tau_{1}}}\right]+$ $\beta_{3} \cdot\left[\frac{1-e^{\frac{-T T M}{\tau_{2} 1}}}{T T M / \tau_{2}}-e^{\frac{-T T M}{\tau_{2}}}\right]$. See Svenson $(1995$ for details.

Table 13: Datascreening Corporate Bonds

This tables describes the bond sample selection process for the corporate bonds used in my analysis.

\begin{tabular}{|c|c|c|}
\hline Variable & Filter & Value \\
\hline Country of Risk ${ }^{(1)}$ & INCLUDE & $\begin{array}{l}\text { Europe (except "United Kingdom" } \\
\text { and "Switzerland") }\end{array}$ \\
\hline BICS Classification $^{(2)}$ & INCLUDE & All (except "Financials" and "Government") \\
\hline Payment Rank ${ }^{(3)}$ & INCLUDE & $\begin{array}{l}\text { "Junior Unsecured", "Sr Unsecured" } \\
\text { "Jr Subordinated", "Subordinated", } \\
\text { "Unsecured" }\end{array}$ \\
\hline Issue Date $\mathrm{D}^{(4)}$ & LESS THAN & $06 / 06 / 2012$ \\
\hline Maturity Date ${ }^{(5)}$ & IN RANGE & $01 / 01 / 2015-12 / 30 / 2019$ \\
\hline Maturity Type ${ }^{(6)}$ & INCLUDE & Bullet \\
\hline Currency $^{(7)}$ & INCLUDE & Euro (EUR) \\
\hline
\end{tabular}

Explanation:

(1) I choose all corporate bonds whose ultimate risk are located in Europe. Bonds by UK or Swiss companies are dropped to create a sample that is comparable to the bank bonds.

(2) To get a proper control sample I use only non-financials and non-government bonds (the latter would be to correlated with the safe yield to have meaningful information)

(3) Similarly to the bank bond sample, secured bonds are excluded to create a sample that is comparable to the bank bonds.

(4) Only bonds issued before the reform are considered

(5) Only bonds maturing after the reform was passed are considered.

(6) I include only bullet bonds

(7) To be able to compute the yield spread I only use bond yields of Euro denominated bonds 


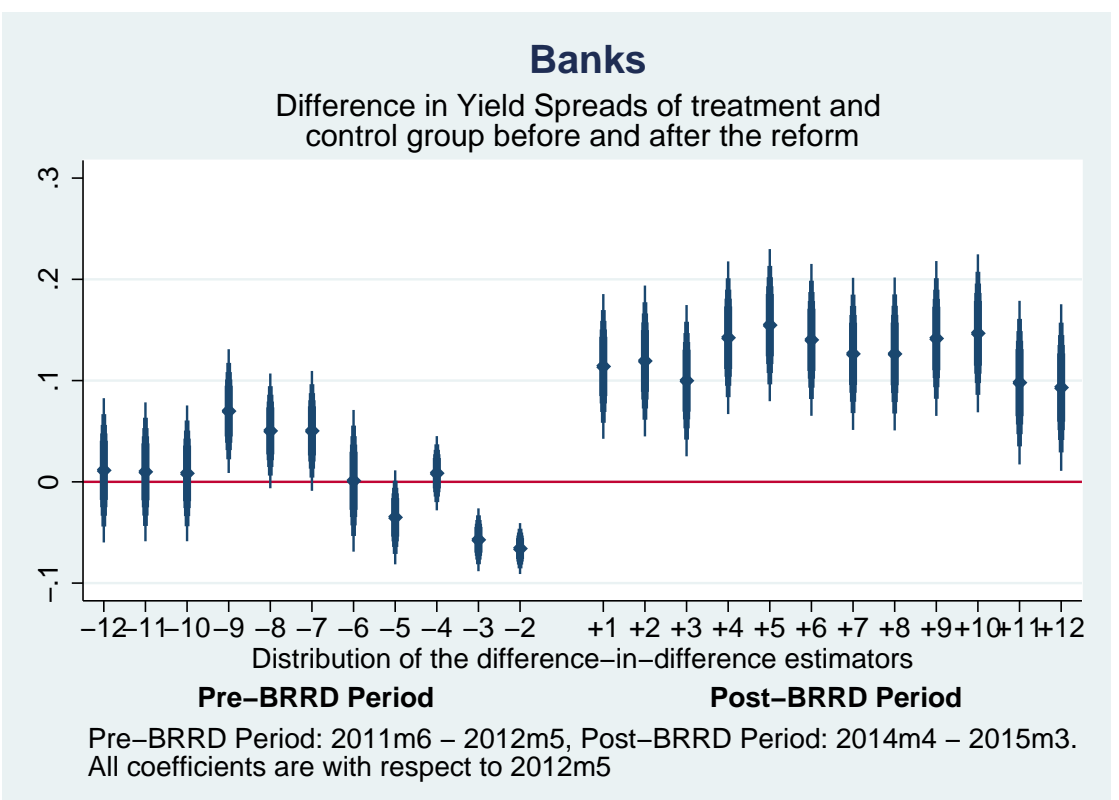

(a) Banks

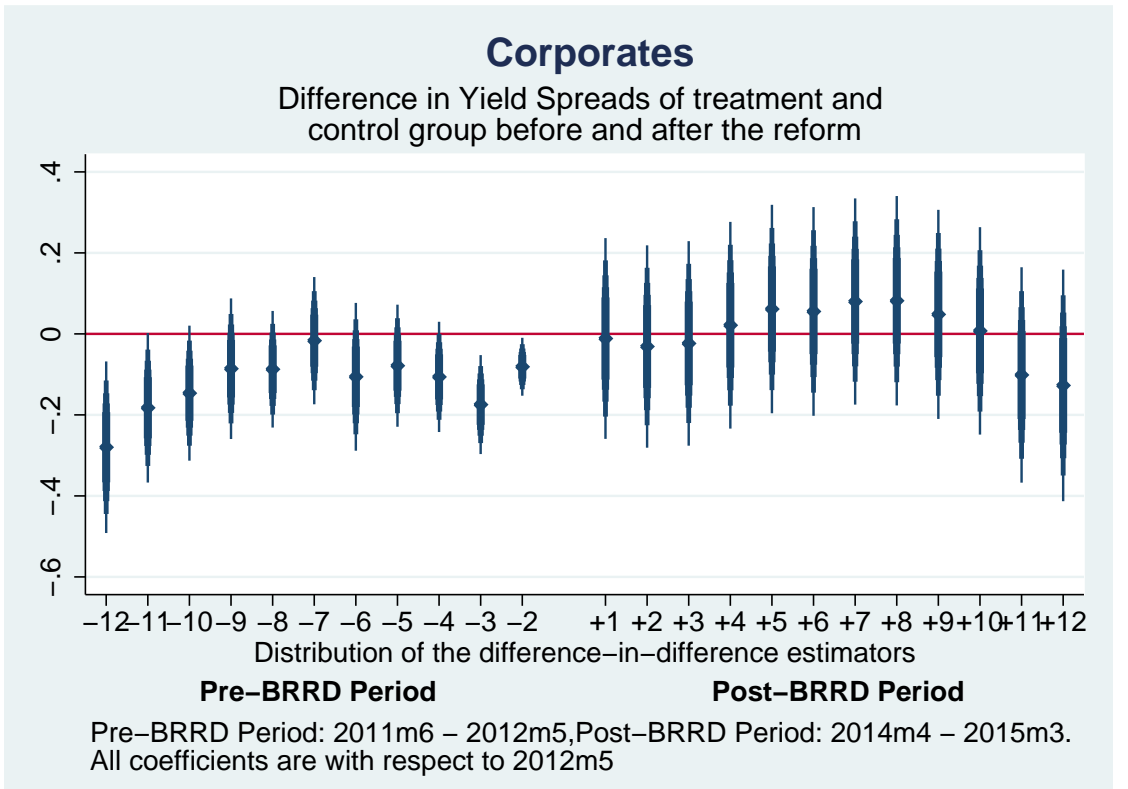

(b) Corporates

Figure 3: Parallel trends test in bank and corporate bond samples

The graphs plot the difference-in-difference estimators along with their $90 \%$ confidence intervals for the (a) bank and (b) the non-bank corporate sample esrimated by equation (3), where standard errors are clustered on bond level. Clearly for both sample the parallel trend assumption can be maintained (all lags are statistically insignificant from zero) in the pre-BRRD period. For banks however, the treatment group (i.e. bonds maturing in 2016 which are subject to BRRD bail-in) face significantly higher yield spreads under the new bail-in regime. All specifications include bond and bank $\times$ month fixed effects and control for residual maturity as defined in equation (1). 


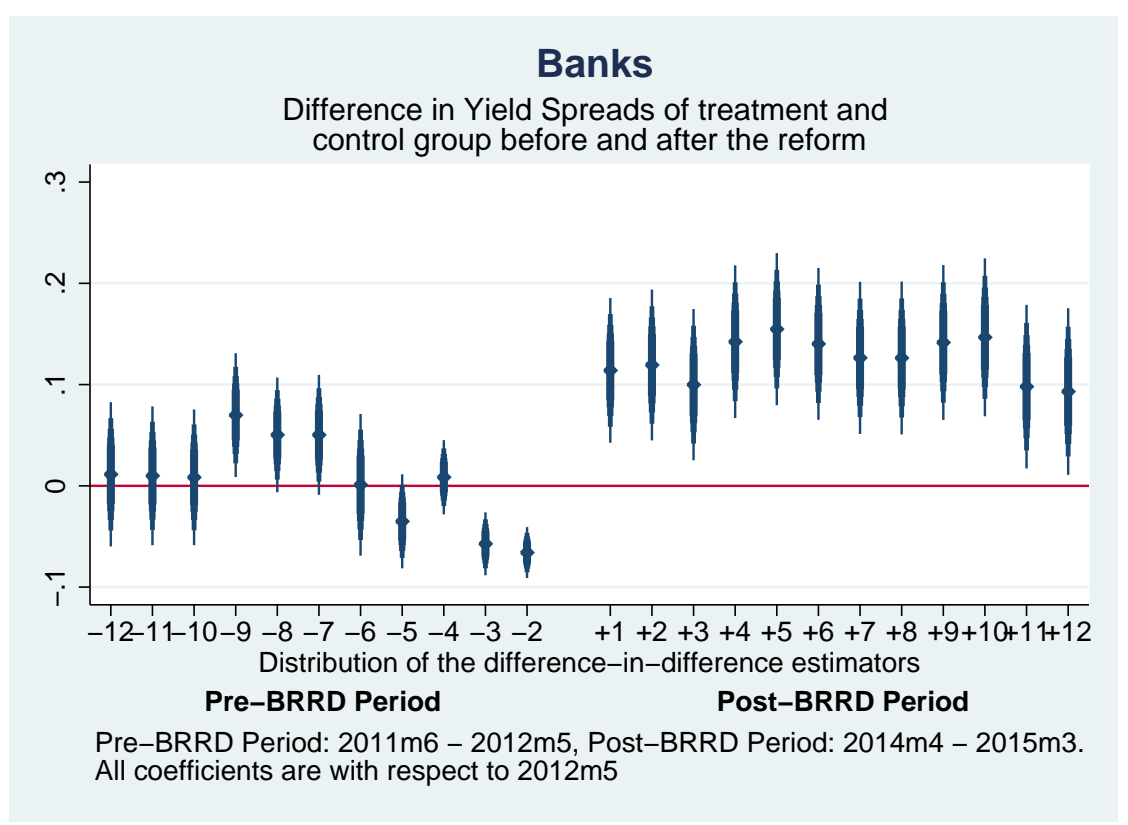

(a) Banks

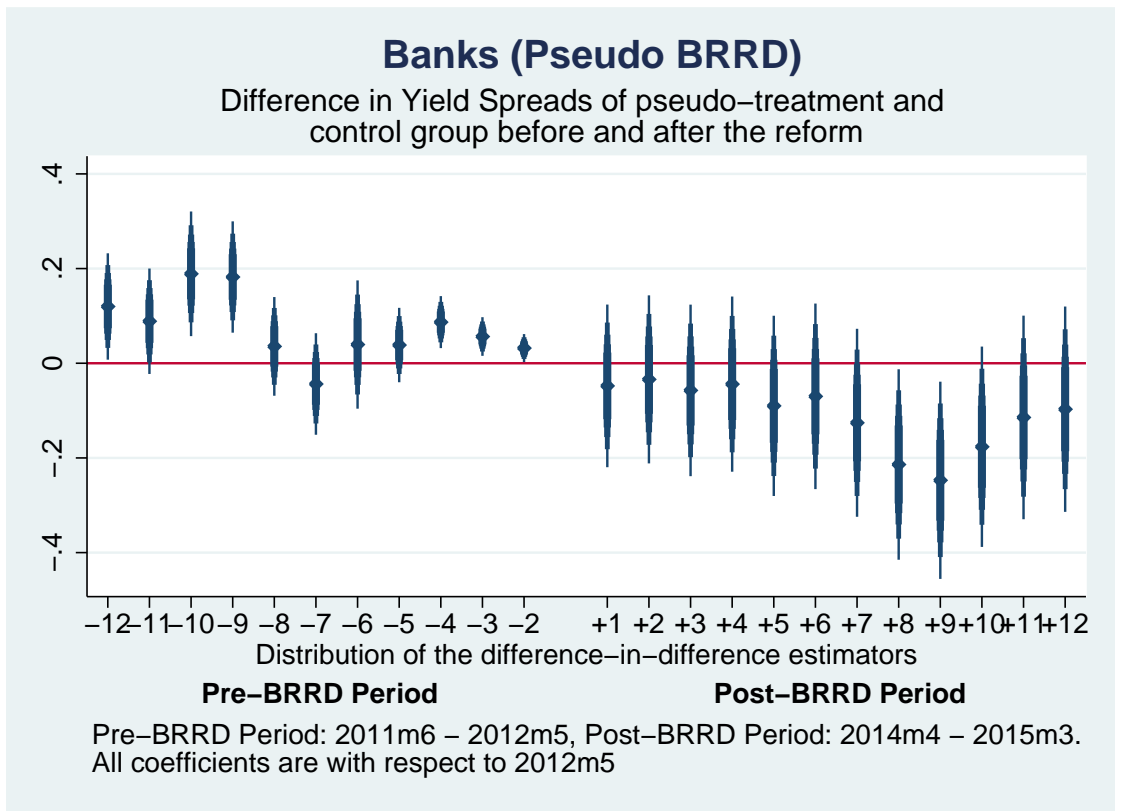

(b) Banks (Pseudo BRRD)

Figure 4: Parallel trends test in bank and pseudo BRRD bond samples

The graphs plot the difference-in-difference estimators along with their $90 \%$ confidence intervals for the (a) bank and (b) the non-bank corporate sample esrimated by equation (3), where standard errors are clustered on bond level. Clearly for both sample the parallel trend assumption can be maintained (all lags are statistically insignificant from zero) in the pre-BRRD period. For banks however, the treatment group (i.e. bonds maturing in 2016 which are subject to BRRD bail-in) face significantly higher yield spreads under the new bail-in regime. All specifications include bond and bank $\times$ month fixed effects and control for residual maturity as defined in equation (1). 


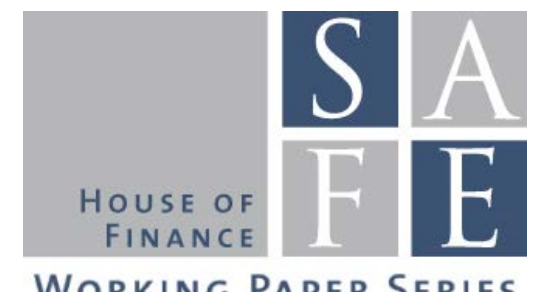

WORKING PAPER SERIES

\section{Recent Issues}

No. 231 Benjamin Clapham, Peter Gomber, Jens Lausen, Sven Panz

No. 230 Yalin Gündüz, Giorgio Ottonello, Loriana Pelizzon, Michael

Schneider, Marti G.

Subrahmanyam

No. 229 Daniel Harenberg

No. 228 Roberto C. Panzica

No. 227 Mila Getmansky, Ravi

Jagannathan, Loriana Pelizzon,

Ernst Schaumburg, Darya Yuferova

No. 226 Loriana Pelizzon, Marti G.

Subrahmanyam, Davide Tomio, Jun Uno

No. 225 Monica Billio, Massimiliano Caporin, Lorenzo Frattarolo, Loriana Pelizzon

No. 224 Giulio Girardi, Kathleen W. Hanley, Stanislava Nikolova, Loriana Pelizzon, Mila Getmansky Sherman

No. 223 Florian Deuflhard

No. 222 Vanessa Endrejat, Matthias Thiemann

No. 221 Axel H. Börsch-Supan, Klaus Härtl, Duarte N. Leite, Alexander Ludwig

No. 220 Yangming Bao, Martin R. Goetz
Liquidity Provider Incentives in Fragmented Securities Markets

Lighting up the Dark: Liquidity in the German Corporate Bond Market

Asset Pricing in OLG Economies With Borrowing Constraints and Idiosyncratic Income Risk

Idiosyncratic Volatility Puzzle: The Role of Assets' Interconnections

Stock Price Crashes: Role of Slow-Moving Capital

\section{Central Bank-Driven Mispricing?}

Networks in risk spillovers:

A multivariate GARCH perspective

Portfolio Similarity and Asset Liquidation in the Insurance Industry

Quantifying Inertia in Retail Deposit Markets

Reviving the Shadow Banking Chain in Europe: Regulatory Agency, Technical Complexity and the Dynamics of CoHabitation

Endogenous Retirement Behavior of Heterogeneous Households Under Pension Reforms

Local Peer Effects and Corporate Investment 